\title{
Keap1 moderates the transcription of virus induced genes through G9a-GLP and NFKB p50 recruitment,
}

\section{and H3K9me2 deposition}

Veronica Elizabeth Burns and Tom Klaus Kerppola\#

Department of Biological Chemistry, University of Michigan, Ann Arbor, MI 48109-5606

Running head: Keap1 moderates transcription of virus induced genes

Keywords: Sendai virus induced gene transcription; moderation of transcription; virus induced chromatin modification; lysine methyltransferase recruitment; stability of chromatin binding; sentinel cell gene regulation

\section{Abstract}

Cells must moderate transcription that is induced by virus infection to mitigate deleterious consequences of inflammation. We investigated the mechanisms whereby Keap1 moderates the transcription of genes that are induced by Sendai virus infection in mouse embryo fibroblasts (MEFs). Virus infection induced Keap1 to bind Ifnb1, Tnf and I/6, and reduced Keap1 binding at Cdkn1a and Ccng1. Keap1 was required for G9a and GLP to bind and to deposit H3K9me2 at these genes upon virus infection. Keap1 moderated the transcription of genes that were induced by virus infection in concert with G9a, GLP, and NFKB p50 recruitment. G9a-GLP lysine methyltransferase activity was required for Keap1 to moderate the transcription of virus induced genes. G9a-GLP inhibitors enhanced the transcription of virus induced genes, and they augmented Keap1 and NFKB p50 recruitment, in parallel with the inhibition of H3K9me2 deposition. The interdependent effects of Keap1 and G9a-GLP on transcription and on the recruitment of each other constitute a feedback circuit that moderates the transcription of virus induced genes. G9a-GLP inhibitors augmented Keap1 binding to different genes in virus infected and in uninfected MEFs, whereas they inhibited H3K9me2 deposition that was induced by virus infection selectively. G9a-GLP inhibitors stabilized Keap1 retention in permeabilized MEFs and augmented Keap1 binding to specific genes in parallel. Keap1 was required for NFKB p50 recruitment, and for the augmentation of NFKB binding by G9a-GLP inhibitors. Keap1 and the electrophile $\mathrm{tBHQ}$ attenuated virus induced gene transcription through independent mechanisms, and they regulated the recruitment of different NFKB subunits. 


\section{Importance}

Excess and maladaptive immune responses to virus infections are a major contributing factor to the morbidity and mortality of COVID-19 and other diseases. Conversely, inadequate immune responses to vaccines and pathogens by individuals with suppressed immune function expose them to infections. Currently available drugs that enable therapeutic management of immune responses have low specificity and can blunt beneficial immune functions. The molecular mechanisms that moderate the transcription of genes that are induced by virus infection are incompletely understood. Characterization of the mechanisms whereby Keap1, G9a-GLP and NFKB p50 moderate virus induced gene transcription in mouse embryo fibroblasts represents the first step toward the identification of new targets for therapeutic agents that can modulate immune responsiveness.

\section{Introduction}

Genes that are induced upon virus infection protect organisms from pathogenesis. Excess transcription of virus induced genes has deleterious effects. Elucidation of the factors and molecular mechanisms that moderate the transcription of virus induced genes is necessary to understand how homeostasis is maintained during viral infections.

Keap1 (Kelch-like ECH-associated protein) deletion can cause spontaneous inflammation in several mouse organs as well as reduce experimentally induced inflammatory responses. Germline Keap1 deletion combined with conditional Nrf2 deletion in keratinocytes causes kidney inflammation that is associated with hydronephrosis and polyuria (1). Conditional Keap1 deletion in Tregs causes lung and liver inflammation (2). Conversely, conditional Keap1 deletions in Clara cells, in macrophages and granulocytes, in thymocytes, and in renal tubule cells reduce experimentally induced inflammatory responses (3-6). Since Keap $1^{f l}$ alleles can be hypomorphic and their deletion is frequently inefficient, conditional Keap1 deletion may not produce loss of function phenotypes. The pro- and anti-inflammatory effects of Keap1 deletions suggest that Keap1 influences immune functions through multiple mechanisms. To characterize the roles of Keap1 in immune regulation it is important to identify the cellular and molecular processes that mediate Keap1 effects on immune functions. 
bioRxiv preprint doi: https://doi.org/10.1101/2022.02.08.479619; this version posted February 10, 2022. The copyright holder for this preprint (which was not certified by peer review) is the author/funder, who has granted bioRxiv a license to display the preprint in perpetuity. It is made available under aCC-BY-NC 4.0 International license.

Keap1 depletion can enhance or reduce the induction of cytokine transcription in cultured cells. Keap1 depletion in RAW 264.7 and THP-1 macrophages/monocytes enhances //6 induction by LPS (7). Similarly, Keap1 depletion in human primary monocyte derived macrophages enhances inflammatory cytokine induction by Mycobacterium avium infection (8). These increases in cytokine induction correlate with increases in IKK $\alpha / \beta$ levels and phosphorylation $(7,8)$. In contrast, conditional Keap1 deletion in mouse bone marrow derived macrophages reduces cytokine induction by LPS and IFN $\gamma(9)$. This reduction of cytokine induction correlates with an increase in Nrf2. The contrasting effects of Keap1 depletion on cytokine induction in different macrophages could be due to indirect effects of Keap1 depletion, or they could be due to differences in the immune exposures of the macrophages prior to Keap1 depletion. To identify the direct and innate effects of Keap1 on cytokine transcription, it is important to determine how Keap1 regulates transcription in cells that have not been altered by prior immune exposures.

Fibroblasts respond rapidly to virus infection and serve as sentinel cells of the immune system (10). Lymphocytic choriomeningitis virus infection in mice induces immune response genes in the fibroblasts of many organs (11). Influenza virus infection in mice induces changes in lung fibroblast gene expression in regions of interstitial inflammation (12). Fibroblasts are a major constituent of the tumor microenvironment, which influences immune responses to tumor initiation, tumor growth, and immune checkpoint inhibitor therapeutics. Mouse embryo fibroblasts (MEFs) can be used to study mechanisms of gene regulation in naïve cells that have not been exposed to immune responses. Understanding of the mechanisms for regulation of the transcription of virus induced genes in MEFs provides a basis for the investigation of transcription regulation in other cells that control immune functions.

Sendai virus infection induces Keap1 to bind cytokine genes in MEFs (13). The levels of cytokine transcripts are higher in virus infected Keap1-/- MEFs than in MEFs with intact Keap1, suggesting that Keap1 moderates cytokine induction. To elucidate how Keap1 moderates the transcription of virus induced genes, it is necessary to determine the effects of Keap1 on transcription factor binding and on chromatin modifications, and their reciprocal effects on Keap1 binding to chromatin. 
bioRxiv preprint doi: https://doi.org/10.1101/2022.02.08.479619; this version posted February 10, 2022. The copyright holder for this preprint (which was not certified by peer review) is the author/funder, who has granted bioRxiv a license to display the preprint in perpetuity. It is made available under aCC-BY-NC 4.0 International license.

Keap1 binding to chromatin was discovered on Drosophila polytene chromosomes $(14,15)$. Keap1 binds to Drosophila genomic loci that encompass genes that are associated with innate immunity as well as other functions. It is important to compare the effects of virus infection on Keap1 binding to different classes of genes.

The G9a (encoded by Ehmt2) and GLP (encoded by Ehmt1) lysine methyltransferases catalyze histone H3 lysine 9 dimethylation (H3K9me2) (16). They have overlapping and interdependent activities (17). They are required for the differentiation and functions of both innate and adaptive immune cells (18-20). G9a and GLP are associated with the repression of cytokine transcription (21-23). It is important to determine the effects of virus infection on G9a and GLP binding to virus induced genes and the relationships between Keap1 and G9a-GLP recruitment.

Many pharmacological inhibitors of G9a and GLP have been developed (24-27). These compounds inhibit G9a and GLP lysine methyltransferase activities through different mechanisms and with different potencies. G9a and GLP can methylate substrates other than $\mathrm{H} 3$, and some functions of G9a and GLP do not require their lysine methyltransferase activities $(18,28)$. It is important to determine if H3K9me2 deposition or other G9a and GLP activities moderate regulatory protein binding to chromatin, or the transcription of virus induced genes.

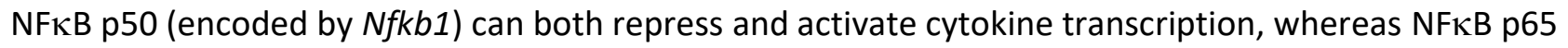
(encoded by RelA) activates transcription (29-33). Conditional $N f k b 1$ deletion in dendritic cells or in follicular B cells of bone marrow chimeric mice causes autoimmunity $(34,35)$. Heterozygous loss of function mutations in NFKB1 are associated with both sporadic and familial common variable immunodeficiency $(36,37)$. Many of these patients present with autoinflammatory or autoimmune complications $(38,39)$. It is important to identify the differences in NFKB p50 and NFKB p65 regulation that can contribute to their distinct effects on immune functions,

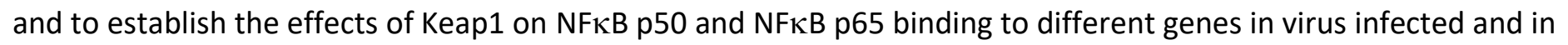
uninfected cells.

Keap1 binds electrophiles and represses electrophile response gene transcription through interaction with Nrf2. Some electrophiles reduce cytokine induction and autoinflammatory reactions (40). Dimethylfumarate is 
used to treat psoriasis and multiple sclerosis. The potential roles of Keap1 in electrophile effects on

immunomodulatory gene transcription need to be evaluated.

We tested the hypothesis that Sendai virus infection induces Keap1 to bind specific genes, and that Keap1 moderates the transcription of those genes. We examined the relationships between Keap1 and G9a-GLP recruitment and $\mathrm{H} 3 \mathrm{~K} 9 \mathrm{me} 2$ deposition at virus induced genes, and the interdependence of their effects on virus induced transcription. We investigated the roles of lysine methyltransferase activity in G9a-GLP effects on transcription and on recruitment of other proteins at virus induced genes by using several structurally dissimilar G9a-GLP inhibitors. We compared the effects of Keap1 on NFKB p50 and NFKB p65 binding to different genes and to proximal and distal elements. We also compared the effects of Keap1 and of electrophiles on transcription and

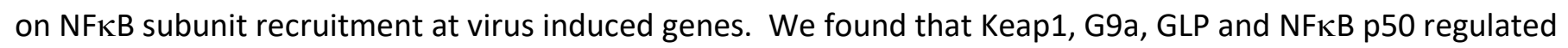
recruitment of each other, and moderated transcription at virus induced genes through H3K9me2 deposition.

\section{Results}

We compared the effects of Keap1 on the transcription of genes that were induced by Sendai virus infection and of uninduced genes in MEFs. We measured the transcript levels in MEFs with intact Keap1 and in MEFs with Keap1-/- deletions (Fig. 1A). To avoid the indirect effects of Keap1-/- deletions that result from constitutive Nrf2 activation, we focused on the effects of Keap1-/- deletions in MEFs that also carried Nrf2-/deletions (Keap1-/- MEFs). We measured transcript levels at different times after virus infection to characterize the effects of Keap1 on the primary transcriptional response.

Virus infection induced $/ f n b 1, T n f$ and $/ / 6$ transcription more rapidly and to higher levels in Keap1-/- MEFs than in MEFs with intact Keap1 (Fig. 1A). The higher transcript levels were observed beginning at $2 \mathrm{~h}$ after virus infection. The peak Ifnb1, Tnf and II6 transcript levels were 3- to 8-fold higher on average in 7 different sets of Keap1-/- MEFs relative to MEFs with intact Keap1. Keap1 reduced the levels of virus induced transcripts at the earliest times after infection that were tested by mechanisms that were independent of Nrf2, consistent with direct moderation of the transcription of virus induced genes by Keap1. 
bioRxiv preprint doi: https://doi.org/10.1101/2022.02.08.479619; this version posted February 10, 2022. The copyright holder for this preprint (which was not certified by peer review) is the author/funder, who has granted bioRxiv a license to display the preprint in perpetuity. It is made available under aCC-BY-NC 4.0 International license.

We examined the effects of Keap1 on cell cycle associated gene transcription because Keap1 interacts with

DNA replication factors, and because the stability of Keap1 retention in the nucleus varies at different stages of the cell cycle (41). The basal levels of Cdkn1a and Ccng1 transcripts were higher in Keap1-/- MEFs than in MEFs with intact Keap1 (Fig. 1A). Virus infection induced Cdkn1a transcription in two of the three independent Keap1-/- MEFs that were tested. In contrast, virus infection did not induce Cdkn1a transcription in MEFs with intact Keap1. Latent virus induced transcription of Cdkn1a was suppressed in MEFs with intact Keap1.

There was no difference in the accumulation of Sendai virus M gene transcripts between Keap1-/- MEFs and MEFs with intact Keap1 at early times after virus infection (Fig. 2A). This indicates that Keap1 did not affect the efficiencies of virus infection or replication. The small effects of virus infection on Ccng1, Gapdh and Nqo1 transcription did not differ between Keap1-/- MEFs and MEFs with intact Keap1 (Fig. 1A, 2A, 3B). Keap1 reduced the levels of virus induced transcripts selectively.

We compared the effects of Keap1 on virus induced gene (Ifnb1, Tnf and I/6) transcription and on electrophile response gene (Nqo1) transcription in MEFs with intact Nrf2 and in MEFs with Nrf2-/- deletions. The Nqo1 transcript level was 50-fold higher in Keap1-/- MEFs with intact Nrf2 than in MEFs with intact Keap1 and Nrf2. There was little difference in Nqo1 transcript levels between Keap1-/- Nrf2-/- MEFs and Nrf2-/- MEFs (Fig. 1). In contrast, virus infection induced higher Ifnb1, Tnf and I/6 transcript levels in Keap1-/- Nrf2-/- MEFs than in Nrf2-/MEFs (Fig. 1). The smaller effects of Keap1-/- deletions on Ifnb1, Tnf and I/6 transcription in MEFs with intact Nrf2 than in MEFs that also contained Nrf2-/- deletions could be attributable to the effects of Keap1-/- deletions on the growth rate and NFKB activation in MEFs with intact Nrf2, but not in MEFs with Nrf2-/- deletions (13). Keap1 moderated the transcription of virus induced genes by mechanisms that did not require Nrf2, and that were distinct from Keap1 regulation of electrophile response gene transcription.

\section{Virus infection induces Keap1 to bind cytokine genes and reduces Keap1 binding at cell cycle genes}

We compared the effects of virus infection on Keap1 binding to the promoter regions of cytokine and cell cycle associated genes. Virus infection induced Keap1 to bind Ifnb1, Tnf and I/6 in the 7 independent MEFs with intact Keap1 that were tested, and not in Keap1-/- MEFs (Fig. 1B, 1C). The $\alpha$ Keap1 ChIP signals at these genes were 
bioRxiv preprint doi: https://doi.org/10.1101/2022.02.08.479619; this version posted February 10, 2022. The copyright holder for this preprint (which was not certified by peer review) is the author/funder, who has granted bioRxiv a license to display the preprint in perpetuity. It is made available under aCC-BY-NC 4.0 International license.

11- to 14-fold higher, on average, in virus infected MEFs than in uninfected MEFs. We determined that the ChIP signals reflected Keap1 binding to virus induced genes by using antibodies that recognized different epitopes in Keap1 and by employing several independent criteria to establish the validity of the ChIP signals. Since Keap1 bound to these genes upon virus infection, and since the levels of these transcripts were higher in Keap1-/- MEFs, we inferred that Keap1 moderated their transcription by binding to the genes upon virus infection.

Keap1 bound to Cdkn1a and Ccng1 in uninfected MEFs. Virus infection reduced Keap1 binding to these genes in the 4 independent MEFs that were tested (Fig. 1B, 1C). The $\alpha$ Keap1 ChIP signals at Cdkn1a and Ccng1 were $21 \%$ and $23 \%$ lower, on average, in virus infected MEFs than in uninfected MEFs. The differences in the effects of virus infection on Keap1 binding to Ifnb1, Tnf and II6 versus Cdkn1a and Ccng1 suggest that virus infection regulated Keap1 binding to different genes by selective mechanisms.

\section{Keap1 is necessary but not sufficient for G9a and GLP to bind and to deposit H3K9me}

G9a and GLP bind to cytokine genes in virus infected MEFs with intact Keap1, but not in Keap1-/- MEFs (13). We compared G9a and GLP binding at different classes of genes in virus infected and in uninfected MEFs with intact Keap1 and with Keap1-/- deletions to investigate the relationships among Keap1, G9a and GLP binding. Virus infection induced G9a and GLP to bind Ifnb1, Tnf and I/6 in the 3 independent MEFs with intact Keap1 that were tested (Fig. 1B). Virus infection also induced G9a and GLP to bind Cdkn1a and Ccng1, and $10 \mathrm{~kb}$ upstream of Ifnb1 in MEFs with intact Keap1. Virus infection did not induce G9a or GLP to bind the genes that were examined in Keap1-/- MEFs. The $\alpha \mathrm{G} 9$ a and $\alpha$ GLP ChIP signals at these genes were 3- to 7-fold higher on average in virus infected MEFs with intact Keap1 than in Keap1-/- MEFs. Since Keap1 was required for both G9a and GLP binding, and since both G9a and GLP have lysine methyltransferase activity and can form heterodimers, we refer to these complexes collectively as G9a-GLP. Keap1 was required for G9a-GLP recruitment both to virus induced genes and to genes that are not induced by virus infection in virus infected MEFs, but Keap1 binding to chromatin was not sufficient for G9a-GLP recruitment in uninfected MEFs.

Since G9a-GLP catalyze histone H3K9 dimethylation, we examined the effects of virus infection on H3K9me2 at different genes in MEFs with intact Keap1 and in MEFs with Keap1-/- deletions. Virus infection 
induced $\mathrm{H} 3 \mathrm{~K} 9 \mathrm{me} 2$ at the genes that were examined in the 6 independent MEFs with intact Keap1 that were tested

(Fig. 1B). By contrast, virus infection did not increase H3K9me2 at these genes in Keap1-/- MEFs. It is likely that the lack of virus induced H3K9me2 deposition in Keap1-/- MEFs was due to the lack of virus induced G9a or GLP binding. Significantly, the basal H3K9me2 levels were the same in Keap1-/- MEFs and in MEFs with intact Keap1, indicating that Keap1 affected virus induced $\mathrm{H} 3 \mathrm{~K} 9 \mathrm{me} 2$ deposition selectively. Virus infection reduced H3K27me3 at these genes, indicating that the increase in the $\mathrm{H} 3 \mathrm{~K} 9 \mathrm{me} 2$ signal upon virus infection was not due to an increase in chromatin accessibility (Fig. 3A). Additionally, the reduction in H3K27me3 was equivalent in Keap1-/- MEFs and in MEFs with intact Keap1, indicating that Keap1 affected H3K9me2 deposition selectively. Keap1 was required for G9a-GLP to bind and to deposit H3K9me2, and for the moderation of virus induced gene transcription.

\section{Keap1 as well as virus infection have distinct effects on NFKB p50 versus NFKB p65 binding}

NFאB p50 binds to cytokine genes in virus infected MEFs with intact Keap1, but not in Keap1-/- MEFs (13). We compared the effects of Keap1 on the binding of different NFKB subunits and of other transcription factors to different genes in virus infected and in uninfected MEFs. Virus infection induced NFKB p50 to bind Ifnb1 in the 6 independent MEFs with intact Keap1 that were tested (Fig. 1C). Virus infection did not induce NFKB p50 to bind Ifnb1 in 5 independent Keap1-/- MEFs. Virus infection induced different levels of NFאB p50 binding to Tnf in different experiments for reasons that are not known (Fig. 1C, 2B, 3A, 6B). Nevertheless, virus infection induced NFKB p50 to bind Tnf in some experiments with each of the 6 independent MEFs with intact Keap1 that were tested. Virus infection did not induce NFKB p50 to bind Tnf in any experiments with the 5 independent Keap1-/MEFs. NFKB p50 bound to $/ / 6$ in 2 of the 6 uninfected MEFs with intact Keap1, and in all 6 MEFs with intact Keap1 upon virus infection (Fig. 1C, 2B, 3A). NFKB p50 did not bind to //6 in the 5 independent Keap1-/- MEFs in the absence or in the presence of virus. Consequently, Keap1 was required for NFאB p50 to bind Ifnb1, Tnf and I/6 upon virus infection.

NFKB p50 bound to Cdkn1a and Ccng1 in the absence of virus infection in the 5 independent MEFs with intact Keap1 that were tested (Fig. 1B, 2B. 3A). Virus infection augmented NFאB p50 binding to Cdkn1a and Ccng1 
in MEFs with intact Keap1. NFKB p50 did not bind to Cdkn1a or Ccng1 in Keap1-/- MEFs in the absence or in the presence of virus infection. Keap1 was required for NFאB p50 to bind Cdkn1a and Ccng1 in uninfected and in virus infected MEFs.

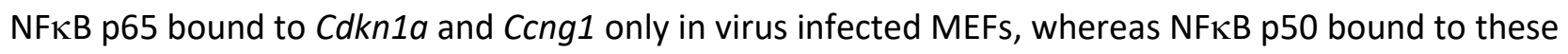
genes also in uninfected MEFs. Virus infection induced equal or higher levels of NFאB p65 binding in Keap1-/- MEFs than in MEFs with intact Keap1 at all genes that were examined, whereas virus infection induced little or no NFאB p50 binding in Keap1-/- MEFs at any of the genes. Thus, both virus infection and Keap1 had distinct effects on

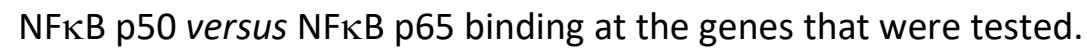

Virus infection induced equivalent levels of IRF3 as well as cJun binding in Keap1-/- MEFs and in MEFs with intact Keap1 at the genes that were tested (Fig. 1B, 1C). Thus, the requirement for Keap1 was unique to G9a-GLP and NFKB p50 recruitment among the chromatin binding proteins that were tested.

\section{G9a-GLP inhibition enhances virus induced gene transcription in MEFs with intact Keap1}

Inhibitors of G9a and GLP lysine methyltransferase activities enhance cytokine transcription and augment Keap1 binding at cytokine genes $(13,23)$. We measured the effects of G9a-GLP inhibitors on virus induced gene transcription in MEFs with intact Keap1 and MEFs with Keap1-/- deletions to investigate the relationships between Keap1 and G9a-GLP in the moderation of virus induced gene transcription. The G9a-GLP inhibitor BIX01294 (42) was added to the MEFs one hour before virus infection to focus on the direct effects of G9a-GLP inhibition.

BIX01294 enhanced Ifnb1, Tnf, and II6 transcription in the 4 independent MEFs with intact Keap1 that were tested (Fig. 2A, left column). The peak Ifnb1, Tnf and I/6 transcript levels were 2.3- to 2.4-fold higher on average in the MEFs with intact Keap1 that were cultured with BIX01294 than in the same MEFs that were cultured with vehicle. In contrast, BIX01294 did not increase the peak Ifnb1, Tnf, or I/6 transcript levels in Keap1-/- MEFs (Fig. 2A, right column). BIX01294 and Keap1-/- deletions separately had quantitatively equivalent effects on Ifnb1 as well as I/6 transcript levels. Since Keap1 moderated the transcription of virus induced genes, and since BIX01294 enhanced the transcription of virus induced genes selectively in MEFs with intact Keap1, we inferred that BIX01294 counteracted the ability of Keap1 to moderate the transcription of virus induced genes. 
bioRxiv preprint doi: https://doi.org/10.1101/2022.02.08.479619; this version posted February 10, 2022. The copyright holder for this preprint (which was not certified by peer review) is the author/funder, who has granted bioRxiv a license to display the preprint in perpetuity. It is made available under aCC-BY-NC 4.0 International license.

BIX01294 did not increase viral M gene transcript accumulation in MEFs with intact Keap1 or in Keap1-/-

MEFs (Fig. 2A). BIX01294 had little or no effect on the levels of Gapdh, Cdkn1a or Cong1 transcripts within $6 \mathrm{~h}$ after virus infection (Fig. 2A, 3B). BIX01294 enhanced virus induced gene transcription rapidly and selectively in MEFs with intact Keap1.

\section{G9a-GLP inhibition augments Keap1 binding to different genes in uninfected and in virus infected MEFs}

We compared the effects of G9a-GLP lysine methyltransferase inhibitors on Keap1 binding to virus induced and to uninduced genes in virus infected and in uninfected MEFs. BIX01294 augmented Keap1 binding to Ifnb1, Tnf and $/ 16$ upon virus infection in the 5 independent MEFs with intact Keap1 that were tested (Fig. 2B, 3B). The aKeap1 ChIP signals at these genes were 1.9- to 2.1-fold higher, on average, in virus infected MEFs that were cultured with BIX01294 than in the same MEFs that were cultured with vehicle. BIX01294 augmented the low $\alpha$ Keap1 ChIP signals at these genes in uninfected MEFs, but these signals remained near the IgG background. The augmentation of Keap1 binding by BIX01294 was detected by antibodies that were raised against different regions of Keap1.

BIX01294 augmented Keap1 binding to Cdkn1a and Ccng1 in uninfected MEFs. The $\alpha$ Keap1 ChIP signals at Cdkn1a and Ccng1 were 1.9 and 2.8 higher, on average, in uninfected MEFs that were cultured with BIX01294, than in the same MEFs that were cultured with vehicle (Fig. 2B).

Whereas virus infection and BIX01294 cooperated to augment Keap1 binding to Ifnb1, Tnf and II6, virus infection counteracted the effects of BIX01294 on Keap1 binding to Cdkn1a and Ccng1. The effects of BIX01294 on Keap1 binding to Cdkn1a and Ccng1 in different virus infected MEFs depended on the efficiency of viral inhibition of Keap1 binding at each gene (Fig. 2B, 3A). Consequently, BIX01294 augmented Keap1 binding to Ifnb1, Tnf and $1 / 6$ mainly in virus infected MEFs, whereas BIX01294 augmented Keap1 binding to Cdkn1a and Ccng1 more efficiently in uninfected MEFs.

\section{G9a-GLP inhibition augments virus induced NFKB binding in MEFs with intact Keap1}

We compared BIX01294 effects on NFKB p50 and NFKB p65 binding to different genes in MEFs with intact Keap1 and in Keap1-/- MEFs. BIX01294 augmented viral induction of NFKB p50 binding to Ifnb1, Tnf and I/6 in the 5 
independent MEFs with intact Keap1 that were tested (Fig. 2B, 3A). The ap50 ChIP signals were 1.6- to 1.9-fold higher, on average, in virus infected MEFs with intact Keap1 that were cultured with BIX01294 than they were in the same MEFs that were cultured with vehicle. The effects of BIX01294 on NFKB p50 binding to Cdkn1a and Ccng1 correlated with BIX01294 effects on Keap1 binding in the same MEFs (Fig. 2B, 3A). BIX01294 did not affect the low ap50 ChIP signals at the genes examined in Keap1-/- MEFs. Since BIX01294 had parallel effects on NFkB p50 and Keap1 binding to the genes that were examined, and since Keap1 was essential for NFKB p50 binding, it is likely that the effects of BIX01294 on NFKB p50 binding were mediated by BIX01294 effects on Keap1 binding to these genes.

BIX01294 augmented NFKB p65 binding to the genes that were examined in virus infected MEFs with intact Keap1 (Fig. 2B). In contrast, BIX01294 did not augment viral induction of NFאB p65 binding to these genes in Keap1-/- MEFs. Thus, Keap1 was specifically required for BIX01294 to augment NFאB p65 binding to these genes, whereas Keap1 was not required for viral induction of NFKB p65 binding. The requirement for Keap1 in the augmentation of NFKB p65 binding by BIX01294 suggests that G9a-GLP moderates NFKB p65 binding only when G9a-GLP binding to the same genes is facilitated by Keap1.

BIX01294 inhibited virus induced H3K9me2 deposition in MEFs with intact Keap1 (Fig. 2B, 3A). In contrast, BIX01294 had no effect on basal H3K9me2 in uninfected MEFs or in Keap1-/- MEFs. BIX01294 did not affect the $\alpha \mathrm{H} 3$ or $\alpha \mathrm{H} 3 \mathrm{~K} 27$ me3 ChIP signals in any of the MEFs (Fig. 3A). The effects of BIX01294 on Keap1 and NFkB p50 binding and on transcription correlated with BIX01294 effects on H3K9me2 deposition at virus induced genes (Ifnb1, Tnf and //6), but not at uninduced genes (Cdkn1a and Ccng1).

\section{Structurally dissimilar G9a-GLP inhibitors augment Keap1 and NFKB p50 binding to virus induced genes.}

We compared the effects of five G9a-GLP inhibitors on Keap1 and on NFKB p50 binding to virus induced genes. MS012 interacts with the peptide binding sites of G9a and GLP (27). MS012 augmented Keap1 and NFKB p50 binding to Ifnb1, Tnf and I/6 in the three independent MEFs with intact Keap1 that were tested (Fig. 3A). The aKeap1 ChIP signals at these genes were 2.3- to 2.7-fold higher, and the $\alpha$ p50 signals were 1.9- to 2.0-fold higher, 
in virus infected MEFs that were cultured with MS012 than in the same MEFs that were cultured with vehicle.

MS012 had parallel effects on Keap1 and on NFאB p50 binding to different genes in virus infected MEFs (Fig. 3A).

MS012 did not affect the low ap50 ChIP signals in Keap1-/- MEFs. MS012 inhibited virus induced H3K9me2

deposition in MEFs with intact Keap1 (Fig. 3A). MS012 augmented Keap1 and NFאB p50 binding and inhibited

H3K9me2 deposition at a lower concentration than BIX01294. The parallel effects of BIX01294 and MSO12 both on

Keap1 and NFKB p50 binding, and on H3K9me2 deposition indicate that these compounds augmented Keap1 and

NFKB p50 binding by inhibiting G9a-GLP lysine methyltransferase activities at virus induced genes.

BRD4770 inhibits lysine methyltransferases by competition with S-adenosyl methionine and its overall

structure differs from those of the other G9a-GLP inhibitors that were tested (26). BRD4770 augmented Keap1 and NFKB p50 binding and inhibited H3K9me2 deposition at virus induced genes in MEFs with intact Keap1 (Fig. 3A).

BRD4770 reduced H3K27me3 at these genes both in MEFs with intact Keap1 and in Keap1-/- MEFs, suggesting that it inhibited lysine methyltransferases other that G9a-GLP independently of Keap1. UNC0638 and UNC0642 augmented Keap1 and NFKB p50 binding and inhibited H3K9me2 deposition at virus induced genes with different efficiencies in different experiments. These differences correlated with differences in their inhibition of H3K9me2 deposition in different MEFs (Fig. 4). Other compounds, including dexamethasone and tert-butylhydroquinone (tBHQ) did not augment Keap1 or NFKB p50 binding to virus induced genes, and had no effect on H3K9me2 deposition (Fig. 6B). Thus, structurally dissimilar G9a-GLP lysine methyltransferase inhibitors augmented Keap1 and NFKB p50 binding, and inhibited H3K9me2 deposition at virus induced genes.

\section{Compounds that inhibit G9a-GLP through different mechanisms enhance virus induced gene transcription in}

\section{MEFs with intact Keap1}

We compared the effects of structurally dissimilar G9a-GLP inhibitors on virus induced gene transcription. BIX01294, MS012 and BRD4770 enhanced Ifnb1, Tnf and II6 transcription in virus infected MEFs with intact Keap1 (Fig. 3B). MSO12 enhanced these transcript levels 2.1- to 2.3-fold on average in the two independent MEFs with intact Keap1 that were tested. BRD4770 enhanced transcription in Keap1-/- MEFs, whereas UNC0638 and 
UNC0642 inhibited transcription in Keap1-/- MEFs (Fig. 3B). These effects could be due to the inhibition of other lysine methyltransferases, as suggested by the reduction of H3K27me3 by BRD4770 (Fig. 3A). BIX01294, MS012 and BRD4770 had little effect on Cdkn1a or Ccng1 transcription and did not increase viral M gene transcript accumulation. The preferential enhancement of virus induced gene transcription by BIX01294, MS012 and BRD4770 in MEFs with intact Keap1 suggests that G9a-GLP inhibition counteracted the ability of Keap1 to moderate the transcription virus induced genes.

\section{Keap1 is required for NFKB p50 to bind the Ccl2 enhancer}

We investigated if Keap1 was required for NFKB p50 to bind the $C c / 2$ enhancer, which is located at a distance from the $C c / 2$ promoter. Virus infection induced Keap1 to bind the $C c / 2$ promoter and NFKB p50 to bind the $C \mathrm{Cl} 2$ enhancer in MEFs with intact Keap1 (Fig. 4). A low level of NFאB p50 bound to the $C c / 2$ promoter. Virus infection did not induce NFKB p50 to bind the Cc/2 enhancer or promoter in Keap1-/- MEFs. Keap1 was required for NFKB p50 to bind the $C \mathrm{Cl} 2$ enhancer, though Keap1 binding was detected mainly at the $C \mathrm{cl} 2$ promoter.

We examined the effects of G9a-GLP inhibitors on Keap1 and NFKB p50 binding to the $C c / 2$ promoter and enhancer. The G9a-GLP inhibitors augmented Keap1 binding to the $C c / 2$ promoter and NFאB p50 binding to the CCl2 enhancer upon virus infection (Fig. 4). The G9a-GLP inhibitors augmented NFkB p50 binding to the Cc/2 enhancer in virus infected MEFs with intact Keap1, and not in Keap1-/- MEFs. The augmentation of Keap1 and NFKB p50 binding to the $C C l 2$ promoter and enhancer by different G9a-GLP inhibitors correlated with the inhibition of virus induced H3K9me2 deposition by these compounds (Fig. 4).

\section{G9a-GLP inhibitors strengthen Keap1 retention in permeabilized MEFs}

To determine if G9a-GLP inhibitors affected the stability of Keap1 interactions in cells, we compared Keap1 retention in MEFs that were cultured with BIX01294 or with vehicle, followed by incubation with detergents. Stronger Keap1 binding to chromatin is predicted to increase Keap1 retention in MEFs. Differences in Keap1 retention in cells have been interpreted to reflect differences in Keap1 binding to chromatin and to other protein complexes $(41,43)$. 
bioRxiv preprint doi: https://doi.org/10.1101/2022.02.08.479619; this version posted February 10, 2022. The copyright holder for this preprint (which was not certified by peer review) is the author/funder, who has granted bioRxiv a license to display the preprint in perpetuity. It is made available under aCC-BY-NC 4.0 International license.

After culture with vehicle, almost all Keap1 was released from the MEFs during incubations with $0.1 \%$ and 0.5\% Triton X-100 (Fig. 5A). In contrast, after culture with BIX01294, most of Keap1 was retained in the MEFs during incubations with $0.1 \%$ and $0.5 \%$ Triton X-100. One fourth of Keap1 was retained in the latter MEFs during incubation with 1\% SDS. Most of Keap1 and histone $\mathrm{H} 3$ were released together from MEFs that were cultured with BIX01294 (Fig. 5A). Culture with BIX01294 did not affect cJun, lamin B1 or histone H3 retention in MEFs during incubations with the detergents that were tested (Fig. 5A). The stabilization of Keap1 retention in MEFs that were cultured with BIX01294 suggests that BIX01294 strengthened Keap1 interactions in MEFs

After culture with vehicle, all NFKB p50 was released from the MEFs during incubations with $0.1 \%$ and $0.5 \%$ Triton X-100 (Fig. 5A). After culture with BIX01294, 10\% of NFKB p50 was retained in the MEFs during incubations with $0.1 \%$ and $0.5 \%$ Triton X-100. BIX01294 did not affect the amount of NFאB p65 that was retained in MEFs.

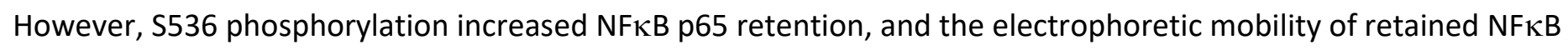
p65 was altered by culture with BIX01294 (Fig. 5A).

The concentration of BIX01294 and the time of culture that stabilized Keap1 retention in MEFs were similar to the conditions that augmented Keap1 binding to specific genes and inhibited H3K9me2 deposition (Fig. 5B, 2B). A lower concentration of MS012 than of BIX01294 was required to stabilize Keap1 retention in MEFs as well as to augment Keap1 binding and inhibit H3K9me2 deposition at specific genes (Fig. 3A). BIX01294 stabilized Keap1 retention in both uninfected and in virus infected MEFs, consistent with BIX01294 augmentation of Keap1 binding to different genes in uninfected and in virus infected MEFs.

Keap1 and electrophiles attenuate the transcription of virus induced genes through opposite effects on different NFKB subunits.

We compared Keap1 and electrophile effects on virus induced gene transcription separately and in combination. Virus infection induced higher levels of Ifnb1 and Tnf transcription in Keap1-/- MEFs than in MEFs with intact Keap1, whether these MEFs were cultured with vehicle or with tBHQ (Fig. 6A). tBHQ reduced and delayed the peak Ifnb1 and Tnf transcript levels to a similar extent both in MEFs with intact Keap1 and in Keap1-/MEFs. tBHQ reduced viral induction of $/ 16$ transcription both in Keap1-/- MEFs and in MEFs with intact Keap1. The 
combined effects of Keap1 and tBHQ suggest that they moderated virus induced gene transcription independently of each other.

We examined if tBHQ affected Keap1 binding to virus induced genes. Culture with tBHQ did not alter Keap1 binding to these genes upon virus infection (Fig. 6B). BIX01294 augmented Keap1 binding to Ifnb1, Tnf and II6 in MEFs that were cultured with tBHQ, suggesting that BIX01294 augmented Keap1 binding to these genes by mechanisms that were unrelated to electrophile responses. The independent effects of Keap1 and of tBHQ on Ifnb1 and Tnf transcription, and the lack of tBHQ effects on Keap1 binding to virus induced genes suggest that Keap1 and tBHQ moderated their transcription through independent mechanisms.

We compared the effects of Keap1 and of tBHQ on NFאB subunit binding to virus induced genes. Keap1

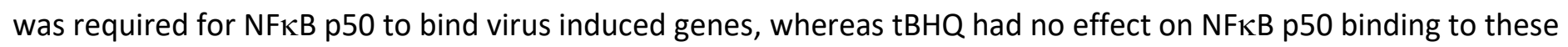
genes (Fig. 6B). In contrast, tBHQ inhibited NFאB p65 binding to these genes both in MEFs with intact Keap1 and in Keap1-/- MEFs, whereas Keap1 did not affect NFאB p65 binding to these genes in the absence of BIX01294. Moreover, tBHQ blocked the augmentation of NFKB p65 binding by BIX01294, whereas it had no effect on the augmentation of NFKB p50 binding in the same MEFs. Both Keap1 and tBHQ attenuated virus induced gene transcription and altered the compositions of NFKB complexes that bound to virus induced genes, but the molecular mechanisms for these effects were distinct.

\section{Discussion}

These experiments have identified a regulatory circuit that moderates the transcription virus induced genes. Virus infection actuated this circuit by inducing Keap1 to bind virus induced genes. The parallel actuation of mechanisms that activate and that moderate the transcription of virus induced genes can shape the timing and the amplitude of virus induced gene transcription in response to signals that modulate their expression.

Viral induction of G9a-GLP binding and H3K9me2 deposition at genes whose transcription is induced by virus infection were unexpected. A recent study found that trivalent influenza virus vaccination increases H3K9me2 and other histone modifications that correlate with reduced transcription in CD34+ progenitors and 
monocyte subsets (44). The increased H3K9me2 correlates with reduced cytokine induction in vitro in PBMCs from vaccinated subjects. Vaccination also reduces chromatin accessibility at cytokine, chemokine and other antiviral response genes in classical monocytes. Chromatin accessibility was reduced within one day after vaccination, suggesting that this is an acute response to vaccination. It is possible that the mechanisms whereby Keap1, G9aGLP and NFKB p50 moderate virus induced gene transcription in MEFs are related to the increased $\mathrm{H} 3 \mathrm{~K} 9 \mathrm{me} 2$ and reduced chromatin accessibility and cytokine induction in monocytes of vaccinated subjects.

Since Keap1 does not contain a recognized DNA binding domain, it is likely that the contrasting effects of virus infection and of G9a-GLP inhibitors on Keap1 binding to virus induced and to uninduced genes were mediated by interactions with different DNA binding proteins at different genes. It is possible that lysine methylation by G9aGLP inhibits some of these interactions, which can account for the higher levels and stability of Keap1 binding to chromatin in MEFs that were cultured with G9a-GLP inhibitors. The molecular mechanisms that induced Keap1 to bind at virus induced genes and reduced Keap1 binding at cell cycle associated genes upon virus infection remain unknown.

Viral induction of Keap1 binding to Ifnb1, Tnf and I/6, and the higher levels of these transcripts in Keap1-/MEFs suggest that Keap1 moderated Ifnb1, Tnf and I/6 transcription in virus infected MEFs by binding to these genes. Keap1 bound to Cdkn1a and Cong1 in uninfected MEFs, and the levels of these transcripts were higher in uninfected Keap1-/- MEFs than in MEFs with intact Keap1. Because many mechanisms can influence the basal levels of these transcripts, and because G9a-GLP inhibitors enhanced Keap1 binding to these genes, but had little effect on their transcription, it is not clear if Keap1 binding to these genes affected their transcription in uninfected MEFs.

Keap1 was required for G9a-GLP and NFKB p50 recruitment and for H3K9me2 deposition both within virus induced genes and in regions flanking these genes. The molecular mechanisms whereby Keap1 facilitated G9a-GLP

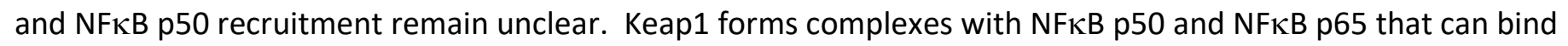
chromatin in living cells, suggesting that they can be recruited in concert. G9a and GLP co-precipitate with NFאB 
subunits from cell extracts, suggesting that they can also be recruited in concert $(22,45)$. It is plausible that initial G9a-GLP binding and H3K9me2 deposition within virus induced genes facilitated.

subsequent G9a-GLP binding and H3K9me2 deposition in flanking regions. It is possible that changes in chromatin structure mediated the effects of Keap1 and G9a-GLP on NFאB p50 binding. The effects of Keap1 and of G9a-GLP inhibitors on NFKB p50 binding to the $C c / 2$ enhancer could also be mediated by DNA looping. This hypothesis is consistent with the observation that both NFKB p50 and Keap1 bind to both the $C \mathrm{C} / 2$ promoter and enhancer.

The absence of G9a-GLP and NFאB p50 binding, and the higher levels of virus induced gene transcription in Keap1-/- MEFs suggest that Keap1 moderated the transcription of virus induced genes by enabling G9a-GLP and NFKB p50 to bind these genes. Because of the interdependent effects of Keap1 and G9a-GLP on chromatin binding by each other and by NFKB p50, it was not possible to distinguish their separate roles in the moderation of virus induced gene transcription. The interdependence of Keap1, G9a-GLP and NFKB p50 binding to, and regulation of, virus induced genes suggest that these proteins are part of a regulatory network whose integrated function moderates the transcription of virus induced genes.

Several structurally and mechanistically dissimilar G9a-GLP inhibitors augmented Keap1 and NFкB p50 binding to virus induced genes and enhanced their transcription. The individual G9a-GLP inhibitors differed in the timing, potency, selectivity and mechanisms of G9a-GLP inhibition. All compounds tested augmented Keap1 and $\mathrm{NF \kappa B}$ p50 binding to virus induced genes, and three of the compounds enhanced virus induced gene transcription in parallel with G9a-GLP inhibition. Consequently, G9a-GLP lysine methyltransferase activities moderate both (1) Keap1 binding to virus induced genes, and (2) virus induced gene transcription.

The augmentation of Keap1 and NFKB p50 binding to virus induced genes and the enhancement of their transcription by G9a-GLP inhibitors correlated with the suppression of virus induced H3K9me2 deposition. The causality of these relationships is supported by the interdependent effects of both Keap1 and G9a-GLP on H3K9me2 deposition, on transcription, and on binding by each other at virus induced genes. G9a-GLP inhibitors enhanced transcription and inhibited H3K9me2 deposition only in MEFs with intact Keap1, suggesting that G9a-GLP 
must bind to virus induced genes in order to moderate their transcription. Because both G9a-GLP binding and lysine methyltransferase activity were required for the moderation of Keap1 and NFKB binding to virus induced genes, and of their transcription, it is likely that H3K9me2 deposition moderated both Keap1 and NFKB binding, and transcription at these genes. Other G9a-GLP substrates can also contribute to these effects of G9a-GLP inhibitors.

The lack of correlations between the effects of G9a-GLP inhibitors on H3K9me2 deposition and on Keap1 binding or on transcription at genes that were not induced by virus infection indicates that H3K9me2 deposition is unlikely to moderate Keap1 binding or transcription at these genes. Virus infection had opposite effects on Keap1 binding to virus induced genes and to uninduced genes, consistent with the hypothesis that different mechanisms control Keap1 binding at different classes of genes. The lack of a correlation between H3K9me2 deposition and Keap1 binding at uninduced genes is also consistent with the lack of G9a-GLP binding to these genes in uninfected MEFs. It is likely that lysine methylation of other G9a-GLP substrates affects Keap1 binding at genes that are not induced by virus infection. The differences in the effects of virus infection and of G9a-GLP inhibitors on Keap1 binding to virus induced and uninduced genes are consistent with the differences in their effects on the transcription of these genes.

G9a-GLP inhibitors augmented Keap1 binding to specific genes and stabilized Keap1 retention in permeabilized MEFs with the same potencies and times of exposure. Keap1 retention varies at different stages of the cell cycle, and is consistent with to chromatin binding (41). Docosahexaenoic acid stabilizes Keap1 retention in human primary monocyte-derived macrophages and reduces CXCL10 and CXCL11 induction by LPS (43). The effects of G9a-GLP inhibitors on Keap1 binding to specific genes and on Keap1 retention in permeabilized MEFs suggest that both properties of Keap1 are regulated by G9a-GLP lysine methyltransferase activity.

The depletion or inhibition of several other lysine methyltransferases and demethylases influences innate immune response gene transcription. Jmjd3 demethylase deletion alters the transcription of a subset of LPS induced genes in mouse macrophages by mechanisms that do not correlate with H3K27me3 levels (46). Kdm2b deletion and KDM5 inhibitors have opposite effects on the transcription of LPS and interferon response genes in 
mouse macrophages versus human cancer cells that do not correlate with the H3K4me3 levels at these genes (47,

48). Ezh2 deletion and inhibitors reduce LPS and poly(l:C) induction of pro-inflammatory genes in mouse

macrophages, and they enhance CXCL10 transcription in tumor cell lines through mechanisms that are unrelated to H3K27me2 deposition at these genes $(49,50)$. The correlation between Keap1 and G9a-GLP effects on H3K9me2 deposition and on the transcription of virus induced genes in MEFs is exceptional among the histone modifications that have been investigated. It is likely that Keap1 influences virus induced transcription also by mechanisms unrelated to G9a-GLP and H3K9me2 deposition. G9a-GLP inhibition had a smaller effect than Keap1-/- deletions on viral induction of Tnf transcription in MEFs. Nevertheless, the interdependent effects of Keap1 deletions and of G9a-GLP inhibitors on their binding to virus induced genes, on H3K9me2 deposition, and on transcription in virus infected MEFs are consistent with interdependent effects of Keap1 and of G9a-GLP on H3K9me2 deposition and on transcription at virus induced genes.

The effects of Keap1 mutations in mice and in human cancers have been attributed to changes in Nrf2 activity $(2-6,51)$. The observations that Keap1 can regulate immunomodulatory gene transcription directly as well as indirectly suggest that the physiological functions of Keap1 can be mediated by many mechanisms $(7,8,13)$. Compounds that alter Keap1 moderation of virus induced gene transcription could be beneficial in the prophylaxis and treatment of infectious diseases and immune disorders.

Acknowledgments. The authors thank Masayuki Yamamoto and Thomas Kensler for mouse strains with the Keap1- and the Nrf2- deletion alleles. The work was funded by funded by National Institutes of Health National Institute on Drug Abuse (DA030339), which had no role in the design or interpretation of the experiments.

\section{Materials and Methods}

Experimental Design. MEFs were derived from embryos with Keap1-/- and Nrf2-/- deletions, or with Nrf2-/- deletions alone. These MEFs were infected with Sendai virus or mock infected. The levels of virus induced gene transcripts and of cell cycle associated gene transcripts were compared at different times after virus infection in multiple independent MEFs of each genotype. The Ifnb1, Tnf and I/6 transcripts were chosen for analysis because they 
were classified in different categories based on previous studies of their activation (52-54). The Cdkn1a and

Cong1 transcripts were chosen for analysis because of the evidence for a role of Keap1 in the cell cycle (41).

Chromatin binding by Keap1 and by other regulators of virus induced gene transcription, and H3K9me2 deposition, were measured by ChIP analyses at virus induced genes and cell cycle associated genes in multiple independent MEFs of each genotype. The binding proteins and H3K9me2 were chyosen for analysis because of previous studies of proteins and histone modifications that correlated with the activation or inhibition of cytokine transcription $(22,23,53)$.

The roles of G9a-GLP lysine methyltransferase activities in transcription and in chromatin binding were examined because Keap1 was required for G9a and GLP recruitment to virus induced genes. Multiple independently derived MEFs of each genotype were cultured with G9a-GLP inhibitors prior to virus infection. The G9a-GLP inhibitors that were tested, and the concentrations and times of culture, were selected based on previous studies of compounds that inhibited G9a and/or GLP activities (24-27).

The effects of G9a-GLP inhibitors on the retention of Keap1, NFkB subunits, and other proteins in permeabilized MEFs were tested because of previous findings that Keap1 can be retained in permeabilized cells $(41,43)$. The effects of tBHQ alone and in combination with Keap1-/- deletions on virus induced gene transcription and regulatory protein binding were examined because of previous studies of Keap1 roles in electrophile response gene regulation.

Derivation of MEFs. Keap1-/- and Nrf2-/- mice $(51,55)$ were crossed to generate Keap1-/+ and Nrf2-/+ heterozygotes. Primary MEFs were isolated from embryos produced by these mice at about 13 days post coitus. The MEFs were expanded for up to 5 passages and any compounds or vehicle were added to the cultures. MEFs from different embryos are identified in the figures and figure legends by \#number after the genotype. All experiments involving live mice were approved by the Institutional Animal Care \& Use Committee at University of Michigan.

MEF culture and Sendai virus infection. The MEFs were cultured in DMEM (GIBCO, cat. no. 11995) supplemented with $10 \% \mathrm{FBS}$ and $0.1 \mathrm{mg} / \mathrm{ml}$ penicillin-streptomycin. MEFs of the indicated genotypes were plated at a density of 
bioRxiv preprint doi: https://doi.org/10.1101/2022.02.08.479619; this version posted February 10, 2022. The copyright holder for this preprint (which was not certified by peer review) is the author/funder, who has granted bioRxiv a license to display the preprint in perpetuity. It is made available under aCC-BY-NC 4.0 International license.

$200,000 / \mathrm{ml}$. When indicated, compounds or vehicle were added to the MEFs at the times indicated prior to virus infection. The MEFs were infected with Sendai virus by the addition of 200 hemagglutinin units/ml of Sendai virus (Charles River Laboratories, Wilmington, MA) or mock infected. For time course analyses, aliquots of the same Sendai virus stock were thawed and added in an identical manner at different times and the cells were harvested and analyzed in parallel.

Analysis of transcript levels by RT-qPCR. The MEFs (200,000 plated cells per sample) were washed twice with prewarmed 1X PBS (Gibco cat. no 10010023), released with 0.05\% trypsin-EDTA (Gibco cat no. 25300054), and suspended in culture medium. Total RNA was isolated (RNeasy, QIAgen) and equal amounts of RNA were reverse transcribed (Transcriptor First Strand cDNA synthesis, Roche). The relative amounts of cDNAs corresponding to the indicated transcripts were measured using qPCR. The relative transcript levels were calculated by assuming that they were inversely proportional to $2^{\mathrm{Ct}}$, where Ct equals the number of cycles required to reach threshold fluorescence. The amounts of transcripts in each sample were normalized by the amount of H3f3a transcripts in the same sample. The average normalized transcript level for duplicate reactions was plotted with upper and lower error bars corresponding to $2 * S D$. The oligonucleotide primers for RT-qPCR were obtained from IDT and validated by melt-curve analyses, and had the following sequences:

\begin{tabular}{|l|l|l|}
\hline RT-qPCR & Forward primer sequence & Reverse primer sequence \\
\hline Ifnb1 & cacagccctctccatcaacta & catttccgaatgttcgtcct \\
\hline Tnf & ttgtcttaataacgctgatttggt & gggagcagaggttcagtgat \\
\hline Il6 & tgccttcatttatcccttgaa & ttactacattcagccaaaaagcac \\
\hline Ccng1 & cacaccaatcagcgacgta & gggaacaagctggagacct \\
\hline Cdkn1a & tccacagcgatatccagaca & ggacatcaccaggattggac \\
\hline M & tggtgctccactcctaccat & gtgcgaccttgtttgcatta \\
\hline Nq01 & agcgttcggtattacgatcc & agtacaatcagggctcttctcg \\
\hline Gapdh & ggccggtgctgagtatgtcgtg & tcggcagaaggggcggagat \\
\hline H3f3a & gccatctttcaattgtgttcg & agccatggtaaggacacctc \\
\hline
\end{tabular}


bioRxiv preprint doi: https://doi.org/10.1101/2022.02.08.479619; this version posted February $10,2022$. The copyright holder for this preprint (which was not certified by peer review) is the author/funder, who has granted bioRxiv a license to display the preprint in perpetuity. It is made available under aCC-BY-NC 4.0 International license.

Analysis of protein binding to specific chromatin regions by ChIP-qPCR. The MEFs (2-8 X $10^{7}$ cells plated for each

genotype and condition) were harvested as described above for transcript analysis. The cells were washed with PBS and crosslinked for $30 \mathrm{~min}$ in $2 \mathrm{ml}$ ice cold 1\% formaldehyde containing 2X Complete EDTA-free Protease Inhibitor Cocktail (Roche). Cross-linking was stopped by the addition of glycine to $333 \mathrm{mM}$. The MEFs were collected and lysed by the addition of $4 \mathrm{ml}$ ice cold cell lysis buffer (5 mM PIPES pH 8.0, $85 \mathrm{mM} \mathrm{KCl}, 0.5 \% \mathrm{NP}-40$, and 2X Complete EDTA-free Protease Inhibitor Cocktail (Roche). The nuclei were collected and lysed by 30 min incubation in 4 ml RIPA buffer containing 1 X PBS, 1\% NP-40, 0.5\% sodium deoxycholate, $0.1 \%$ SDS, 20 mM N-ethylmaleimide, and 2X Complete EDTAfree Protease Inhibitor Cocktail (Roche). The chromatin was sheared by sonication to produce DNA fragments with a size distribution between $500 \mathrm{bp}$ and $1 \mathrm{~kb}$, followed by $14,000 \mathrm{rpm}$ centrifugation at $4 \mathrm{C}$ for $15 \mathrm{~min}$.

The chromatin was divided into 0.5-1 ml aliquots for immunoprecipitation. Each antibody (2-4 $\mu$ g per reaction) and IgG control were incubated with Dynabeads (Invitrogen) for at least $4 \mathrm{~h}$ at $4 \mathrm{C}$ with rotation, washed and resuspended in PBS with BSA. The beads were rotated with the cleared lysates for $24 \mathrm{~h}$ at $4 \mathrm{C}$.

The beads with bound immune complexes were washed 5 times in ice cold $100 \mathrm{mM}$ Tris pH 7.5, $500 \mathrm{mM} \mathrm{LiCl,} 1 \%$ NP-40, 1\% sodium deoxycholate, and once with ice cold $10 \mathrm{mM}$ Tris-HCl pH 7.5, $0.1 \mathrm{mM}$ EDTA. Chromatin complexes were eluted by incubating the beads in $1 \%$ SDS, $0.1 \mathrm{M} \mathrm{NaHCO}$ for $1 \mathrm{~h}$ at $65 \mathrm{C}$. The eluted chromatin complexes as well as aliquots of the input chromatin were incubated for $16-20 \mathrm{~h}$ at $65 \mathrm{C}$ to reverse the crosslinks. The DNA was purified (QIAquick PCR cleanup, Qiagen). The relative amounts of the genes that were precipitated by each antibody were measured by qPCR. The average percentage of the input DNA that was precipitated (ChIP Efficiency) was plotted for duplicate qPCR reactions with upper and lower error bars corresponding to 2 times the standard deviation. The oligonucleotide primers for ChIP-qPCR were obtained from IDT, were validated by melt-curve analyses, and had the following sequences:

\begin{tabular}{|l|l|l|}
\hline ChIP-qPCR & Forward primer sequence & Reverse primer sequence \\
\hline Ifnb1 & attcctctgaggcagaaaggacca & gcaagatgaggcaaaggctgtcaa \\
\hline Tnf & aaccetctgcccccgcgatg & tcctcgctgagggagcttctgc \\
\hline $1 / 6$ & tggggatgtctgtagctcatt & ggaactgccttcacttacttgc \\
\hline
\end{tabular}


bioRxiv preprint doi: https://doi.org/10.1101/2022.02.08.479619; this version posted February 10, 2022. The copyright holder for this preprint (which was not certified by peer review) is the author/funder, who has granted bioRxiv a license to display the preprint in perpetuity. It is made available under aCC-BY-NC 4.0 International license.

\begin{tabular}{|l|l|l|}
\hline Ccng1 & gcaaaacaaaacctcacag & caggtctggcctctattagcc \\
\hline Cdkn1a & ttgcctctcggagaccag & ccaccaggactgaacaga \\
\hline Ifnb1 -10 kb & tcctgcagcattcgtacaag & cattcctctctcccttgc \\
\hline Cc/2 promoter & tgtcgtggattgtgatagcatag & ggctctttgtccttccttctt \\
\hline Ccl2 enhancer & cagagtgaagtgagagggaaac & aagcttcagttagcacaggag \\
\hline
\end{tabular}

Analyses of protein retention in MEFs. The MEFs (200,000 plated cells per sample) were cultured as described above and G9a-GLP inhibitor or vehicle was added at the times indicated. Two different protocols were used to evaluate protein retention in MEFs:

MEF incubation in buffers with successively stronger detergents. The MEFs were permeabilized by resuspension in 0.2 $\mathrm{ml}$ of ice cold CSK buffer containing $0.1 \%$ triton $\mathrm{X}-100,300 \mathrm{mM}$ sucrose, $100 \mathrm{mM} \mathrm{NaCl}, 10 \mathrm{mM}$ imidazole $\mathrm{pH}$ 7, and 2X Complete EDTA-free Protease Inhibitor Cocktail (Roche) for $30 \mathrm{~min}$ on ice. The MEFs were collected by 5 min centrifugation at $4 \mathrm{C}$. The MEFs were resuspended in in $50 \mu \mathrm{l}$ ice cold CSK buffer with $0.5 \%$ triton X-100, for 30 min on ice. The MEFs were collected by 5 min centrifugation at 4 C. The MEFs were suspended in $50 \mu$ l CSK buffer with $1 \%$ SDS, for 30 min at RT. The MEFs were collected by 5 min centrifugation at RT. Each of the supernatants and the final pellet were adjusted to 1 X SDS loading buffer (58.33 mM Tris· Cl, 5\% glycerol, 2.5\% SDS, $0.1 \mathrm{M} \mathrm{DTT,} \mathrm{0.002 \%} \mathrm{bromophenol} \mathrm{blue,}$ $\mathrm{pH}$ 6.8) and boiled for $10 \mathrm{~min}$. The proteins were analyzed by polyacrylamide gel electrophoresis and immunoblotting. MEF incubation in RIPA buffer. The MEFs were permeabilized by resuspending them in $50 \mu$ ice cold RIPA buffer containing 1 X PBS, 1\% NP-40, 0.5\% sodium deoxycholate, 0.1\% SDS, 20 mM N-ethylmaleimide, and 2X Complete EDTAfree Protease Inhibitor Cocktail (Roche) for $30 \mathrm{~min}$ on ice. The MEFs were collected by 5 min centrifugation at $4 \mathrm{C}$. The supernatant and pellet were adjusted to 1 X SDS loading buffer, boiled for $10 \mathrm{~min}$, and analyzed by polyacrylamide gel electrophoresis and immunoblotting.

Antibodies: The $\alpha$ Keap1 (Aviva Systems Biology OACD04962, lot A20190909988) antibody was raised using recombinant Keap1 Met1-Gln286 for immunization. The $\alpha$ Keap1 ${ }^{N}$ (Santa Cruz sc-15246, lot H2603) antibody has an epitope mapping near the $\mathrm{N}$-terminus of human Keap1. The $\alpha$ Keap1 ${ }^{\mathrm{C}}$ (Proteintech 10503-2-AP, lot 00051883) antibody 
bioRxiv preprint doi: https://doi.org/10.1101/2022.02.08.479619; this version posted February 10, 2022. The copyright holder for this preprint (which was not certified by peer review) is the author/funder, who has granted bioRxiv a license to display the preprint in perpetuity. It is made available under aCC-BY-NC 4.0 International license.

was raised using a recombinant human Keap1 325-624 fragment for immunization The specificities of the three $\alpha$ Keap1 antibodies were evaluated by immunoblotting and by performing parallel RT-qPCR as well as ChiP-qPCR experiments using MEFs with Keap1-/- and intact Keap1 alleles. The sources of the other antibodies were as follows: ap50/p105 (Cell Signaling 13586, D4P4d lot 2), ap65 (Cell Signaling 8242, lot 9), aphospho-p65-Ser536 (Cell Signaling 3031, lot 11), $\alpha$ G9a

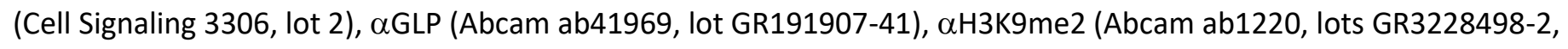

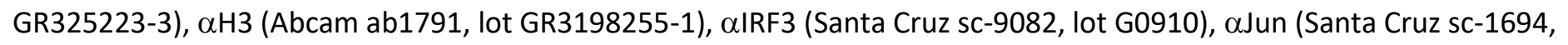
lot E0207), avinculin (Cell Signaling 4650T, lot 4), alaminB1 (Cell Signaling 13435, lot 2), normal rabbit IgG (Santa Cruz sc2027, lot L2414), normal mouse IgG (Santa Cruz sc-2025, lot I2208).

Cell culture supplies and chemicals: DMEM (Gibco 11995) was supplemented with $10 \%(v / v)$ fetal bovine serum (Atlanta Biologicals S11550 lot H1030) and $0.1 \mathrm{mg} / \mathrm{ml}$ penicillin-streptomycin (Gibco 15140). PBS (10010) and 0.05\% trypsin-EDTA solution (25300) were from Gibco. The following compounds were obtained from Cayman Chemical:

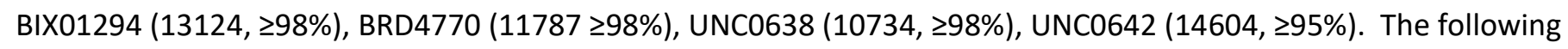
chemicals were obtained from Millipore Sigma: tBHQ (112941, 298\%) and MS012 (SML2174 298\%). These compounds were dissolved in ddH2O (BIX01294) or DMSO (all other compounds) at concentrations ranging from 20 to $50 \mathrm{mM}$. The final concentration of DMSO in experiments using this vehicle was $0.1 \%$. Other chemicals and detergents were purchased from Millipore Sigma and Thermo Fisher Scientific.

Statistical analyses of the likelihood of chance occurrence of observed results. The data that are shown in each figure are representative of data that were obtained from multiple independent experiments that were performed using different sets of MEFs (numbers of independent MEFs are specified in the Figure legends). Each graph shows the means and two times the standard deviation for replicate measurements from one experiment. The results of ANOVA analyses to test hypotheses using data from multiple independent experiments with different sets of MEFs are also indicated in each graph. The p-values for each set of experiments were corrected for multiple testing error by the method of Šidák. These $p$-values were compared to the value indicated in each figure legend to determine if the test supported the acceptance (ns) or rejection $(*)$ of the null hypotheses. The ANOVA tests were performed using the Real Statistics Microsoft Excel plug-in v. 6.8 (Copyright (2013 - 2020) Charles Zaiontz. www.real-statistics.com). ANOVA analyses were performed using data that were obtained from independent experiments. 


\section{References}

1. Suzuki T, Seki S, Hiramoto K, Naganuma E, Kobayashi EH, Yamaoka A, Baird L, Takahashi N, Sato H, Yamamoto M. 2017. Hyperactivation of Nrf2 in early tubular development induces nephrogenic diabetes insipidus. Nature Communications 8:14577.

2. Klemm P, Rajendiran A, Fragoulis A, Wruck C, Schippers A, Wagner N, Bopp T, Tenbrock K, Ohl K. 2020. Nrf2 expression driven by Foxp3 specific deletion of Keap1 results in loss of immune tolerance in mice. Eur J Immunol 50:515-524.

3. Blake DJ, Singh A, Kombairaju P, Malhotra D, Mariani TJ, Tuder RM, Gabrielson E, Biswal S. 2010. Deletion of Keap1 in the lung attenuates acute cigarette smoke-induced oxidative stress and inflammation. American Journal of Respiratory Cell and Molecular Biology 42:524-36.

4. Kong X, Thimmulappa R, Craciun F, Harvey C, Singh A, Kombairaju P, Reddy SP, Remick D, Biswal S. 2011. Enhancing Nrf2 Pathway by Disruption of Keap1 in Myeloid Leukocytes Protects against Sepsis. American Journal of Respiratory and Critical Care Medicine 184:928-938.

5. Noel S, Martina MN, Bandapalle S, Racusen LC, Potteti HR, Hamad ARA, Reddy SP, Rabb H. 2015. T LymphocyteSpecific Activation of Nrf2 Protects from AKI. Journal of the American Society of Nephrology 26:2989-3000.

6. Nezu M, Souma T, Yu L, Suzuki T, Saigusa D, Ito S, Suzuki N, Yamamoto M. 2017. Transcription factor Nrf2 hyperactivation in early-phase renal ischemia-reperfusion injury prevents tubular damage progression. Kidney International 91:387-401.

7. Lv P, Xue P, Dong J, Peng H, Clewell R, Wang A, Wang Y, Peng S, Qu W, Zhang Q, Andersen ME, Pi J. 2013. Keap1 silencing boosts lipopolysaccharide-induced transcription of interleukin 6 via activation of nuclear factor kappaB in macrophages. Toxicol Appl Pharmacol 272:697-702.

8. Awuh JA, Haug M, Mildenberger J, Marstad A, Do CP, Louet C, Stenvik J, Steigedal M, Damas JK, Halaas O, Flo TH. 2015. Keap1 regulates inflammatory signaling in Mycobacterium avium-infected human macrophages. Proc Natl Acad Sci U S A 112:E4272-80.

9. Kobayashi EH, Suzuki T, Funayama R, Nagashima T, Hayashi M, Sekine H, Tanaka N, Moriguchi T, Motohashi H, Nakayama K, Yamamoto M. 2016. Nrf2 suppresses macrophage inflammatory response by blocking proinflammatory cytokine transcription. Nat Commun 7:11624.

10. Davidson S, Coles M, Thomas T, Kollias G, Ludewig B, Turley S, Brenner M, Buckley CD. 2021. Fibroblasts as immune regulators in infection, inflammation and cancer. Nature Reviews Immunology 21:704-717.

11. Krausgruber T, Fortelny N, Fife-Gernedl V, Senekowitsch M, Schuster LC, Lercher A, Nemc A, Schmidl C, Rendeiro AF, Bergthaler A, Bock C. 2020. Structural cells are key regulators of organ-specific immune responses. Nature 583:296-302.

12. Boyd DF, Allen EK, Randolph AG, Guo X-zJ, Weng Y, Sanders CJ, Bajracharya R, Lee NK, Guy CS, Vogel P, Guan W, Li Y, Liu X, Novak T, Newhams MM, Fabrizio TP, Wohlgemuth N, Mourani PM, Kong M, Sanders RC, Irby K, Typpo K, Markovitz B, Cvijanovich N, Flori H, Schwarz A, Anas N, Mourani P, Czaja A, McLaughlin G, Paden M, Tarquinio K, Coates BM, Pinto N, Wardenburg JB, Randolph AG, Agan AA, Novak T, Newhams MM, Kurachek SC, Hartman ME, Doctor A, Truemper EJ, Mahapatra S, Ackerman KG, Daugherty LE, Hall MW, Thomas N, Weiss SL, Fitzgerald $\mathrm{J}$, et al. 2020. Exuberant fibroblast activity compromises lung function via ADAMTS4. Nature 587:466-471.

13. Burns VE, Kerppola TK. 2021. Virus Infection Induces Keap1 Binding to Cytokine Genes, Which Recruits NF-KB p50 and G9a-GLP and Represses Cytokine Transcription. The Journal of Immunology 207:1437-1447.

14. Deng H, Kerppola TK. 2013. Regulation of Drosophila metamorphosis by xenobiotic response regulators. PLoS Genetics 9:e1003263.

15. Deng H, Kerppola TK. 2014. Visualization of the Drosophila dKeap1-CncC interaction on chromatin illumines cooperative, xenobiotic-specific gene activation. Development 141:3277-88.

16. Tachibana M, Sugimoto K, Nozaki M, Ueda J, Ohta T, Ohki M, Fukuda M, Takeda N, Niida H, Kato H, Shinkai Y. 2002. G9a histone methyltransferase plays a dominant role in euchromatic histone H3 lysine 9 methylation and is essential for early embryogenesis. Genes Dev 16:1779-91.

17. Tachibana M, Ueda J, Fukuda M, Takeda N, Ohta T, Iwanari H, Sakihama T, Kodama T, Hamakubo T, Shinkai Y. 2005. Histone methyltransferases G9a and GLP form heteromeric complexes and are both crucial for methylation of euchromatin at H3-K9. Genes Dev 19:815-26. 
bioRxiv preprint doi: https://doi.org/10.1101/2022.02.08.479619; this version posted February 10, 2022. The copyright holder for this preprint (which was not certified by peer review) is the author/funder, who has granted bioRxiv a license to display the preprint in perpetuity. It is made available under aCC-BY-NC 4.0 International license.

18. Lehnertz B, Northrop JP, Antignano F, Burrows K, Hadidi S, Mullaly SC, Rossi FM, Zaph C. 2010. Activating and inhibitory functions for the histone lysine methyltransferase G9a in T helper cell differentiation and function. J Exp Med 207:915-22.

19. Antignano F, Braam M, Hughes MR, Chenery AL, Burrows K, Gold MJ, Oudhoff MJ, Rattray D, Halim TY, Cait A, Takei F, Rossi FM, McNagny KM, Zaph C. 2016. G9a regulates group 2 innate lymphoid cell development by repressing the group 3 innate lymphoid cell program. Journal of Experimental Medicine 213:1153-1162.

20. Mourits VP, van Puffelen JH, Novakovic B, Bruno M, Ferreira AV, Arts RJW, Groh L, Crișan TO, Zwaag J, Jentho E, Kox M, Pickkers P, van de Veerdonk FL, Weis S, Oosterwijk E, Vermeulen SH, Netea MG, Joosten LAB. 2021. Lysine methyltransferase G9a is an important modulator of trained immunity. Clinical \& Translational Immunology 10:e1253.

21. Gazzar ME, Yoza BK, Chen X, Hu J, Hawkins GA, McCall CE. 2008. G9a and HP1 Couple Histone and DNA Methylation to TNF $\alpha$ Transcription Silencing during Endotoxin Tolerance. Journal of Biological Chemistry 283:32198-32208.

22. Ea C-K, Hao S, Yeo KS, Baltimore D. 2012. EHMT1 Protein Binds to Nuclear Factor-KB p50 and Represses Gene Expression. Journal of Biological Chemistry 287:31207-31217.

23. Fang TC, Schaefer U, Mecklenbrauker I, Stienen A, Dewell S, Chen MS, Rioja I, Parravicini V, Prinjha RK, Chandwani R, MacDonald MR, Lee K, Rice CM, Tarakhovsky A. 2012. Histone H3 lysine 9 di-methylation as an epigenetic signature of the interferon response. The Journal of Experimental Medicine 209:661-669.

24. Kubicek S, O'Sullivan RJ, August EM, Hickey ER, Zhang Q, Teodoro ML, Rea S, Mechtler K, Kowalski JA, Homon CA, Kelly TA, Jenuwein T. 2007. Reversal of H3K9me2 by a small-molecule inhibitor for the G9a histone methyltransferase. Mol Cell 25:473-81.

25. Vedadi M, Barsyte-Lovejoy D, Liu F, Rival-Gervier S, Allali-Hassani A, Labrie V, Wigle TJ, Dimaggio PA, Wasney GA, Siarheyeva A, Dong A, Tempel W, Wang SC, Chen X, Chau I, Mangano TJ, Huang XP, Simpson CD, Pattenden SG, Norris JL, Kireev DB, Tripathy A, Edwards A, Roth BL, Janzen WP, Garcia BA, Petronis A, Ellis J, Brown PJ, Frye SV, Arrowsmith $\mathrm{CH}$, Jin J. 2011. A chemical probe selectively inhibits G9a and GLP methyltransferase activity in cells. Nat Chem Biol 7:566-74.

26. Yuan Y, Wang Q, Paulk J, Kubicek S, Kemp MM, Adams DJ, Shamji AF, Wagner BK, Schreiber SL. 2012. A SmallMolecule Probe of the Histone Methyltransferase G9a Induces Cellular Senescence in Pancreatic Adenocarcinoma. ACS Chemical Biology 7:1152-1157.

27. Xiong Y, Li F, Babault N, Dong A, Zeng H, Wu H, Chen X, Arrowsmith CH, Brown PJ, Liu J, Vedadi M, Jin J. 2017. Discovery of Potent and Selective Inhibitors for G9a-Like Protein (GLP) Lysine Methyltransferase. J Med Chem 60:1876-1891.

28. Tachibana M, Matsumura Y, Fukuda M, Kimura H, Shinkai Y. 2008. G9a/GLP complexes independently mediate H3K9 and DNA methylation to silence transcription. The EMBO Journal 27:2681-2690.

29. Bohuslav J, Kravchenko VV, Parry GC, Erlich JH, Gerondakis S, Mackman N, Ulevitch RJ. 1998. Regulation of an essential innate immune response by the p50 subunit of NF-kappaB. The Journal of Clinical Investigation 102:1645-1652.

30. Tato CM, Mason N, Artis D, Shapira S, Caamano JC, Bream JH, Liou H-C, Hunter CA. 2006. Opposing roles of NFKB family members in the regulation of NK cell proliferation and production of IFN- $\gamma$. International Immunology 18:505-513.

31. Wang J, Basagoudanavar SH, Wang X, Hopewell E, Albrecht R, Garcia-Sastre A, Balachandran S, Beg AA. 2010. NF-kappa B RelA subunit is crucial for early IFN-beta expression and resistance to RNA virus replication. J Immunol 185:1720-9.

32. Elsharkawy AM, Oakley F, Lin F, Packham G, Mann DA, Mann J. 2010. The NF-kB p50:p50:HDAC-1 repressor complex orchestrates transcriptional inhibition of multiple pro-inflammatory genes. Journal of Hepatology 53:519-527.

33. Cheng CS, Feldman KE, Lee J, Verma S, Huang D-B, Huynh K, Chang M, Ponomarenko JV, Sun S-C, Benedict CA, Ghosh G, Hoffmann A. 2011. The Specificity of Innate Immune Responses Is Enforced by Repression of Interferon Response Elements by NF-kB p50. Science Signaling 4:ra11.

34. de Valle E, Grigoriadis G, O'Reilly LA, Willis SN, Maxwell MJ, Corcoran LM, Tsantikos E, Cornish JKS, Fairfax KA, Vasanthakumar A, Febbraio MA, Hibbs ML, Pellegrini M, Banerjee A, Hodgkin PD, Kallies A, Mackay F, Strasser A, 
Gerondakis S, Gugasyan R. 2016. NFkB1 is essential to prevent the development of multiorgan autoimmunity by limiting IL-6 production in follicular B cells. Journal of Experimental Medicine 213:621-641.

35. Dissanayake D, Hall H, Berg-Brown N, Elford AR, Hamilton SR, Murakami K, Deluca LS, Gommerman JL, Ohashi PS. 2011. Nuclear factor-kappaB1 controls the functional maturation of dendritic cells and prevents the activation of autoreactive T cells. Nat Med 17:1663-7.

36. Fliegauf M, L. Bryant V, Frede N, Slade C, Woon S-T, Lehnert K, Winzer S, Bulashevska A, Scerri T, Leung E, Jordan A, Keller B, de Vries E, Cao H, Yang F, Schäffer Alejandro A, Warnatz K, Browett P, Douglass J, Ameratunga Rohan V, van der Meer Jos WM, Grimbacher B. 2015. Haploinsufficiency of the NF-kB1 Subunit p50 in Common Variable Immunodeficiency. The American Journal of Human Genetics 97:389-403.

37. Lorenzini T, Fliegauf M, Klammer N, Frede N, Proietti M, Bulashevska A, Camacho-Ordonez N, Varjosalo M, Kinnunen M, de Vries E, van der Meer JWM, Ameratunga R, Roifman CM, Schejter YD, Kobbe R, Hautala T, Atschekzei F, Schmidt RE, Schröder C, Stepensky P, Shadur B, Pedroza LA, van der Flier M, Martínez-Gallo M, Gonzalez-Granado LI, Allende LM, Shcherbina A, Kuzmenko N, Zakharova V, Neves JF, Svec P, Fischer U, Ip W, Bartsch O, Barış S, Klein C, Geha R, Chou J, Alosaimi M, Weintraub L, Boztug K, Hirschmugl T, Dos Santos Vilela MM, Holzinger D, Seidl M, Lougaris V, Plebani A, Alsina L, Piquer-Gibert M, Deyà-Martínez A, et al. 2020. Characterization of the clinical and immunologic phenotype and management of 157 individuals with 56 distinct heterozygous NFKB1 mutations. Journal of Allergy and Clinical Immunology 146:901-911.

38. Kaustio M, Haapaniemi E, Göös H, Hautala T, Park G, Syrjänen J, Einarsdottir E, Sahu B, Kilpinen S, Rounioja S, Fogarty CL, Glumoff V, Kulmala P, Katayama S, Tamene F, Trotta L, Morgunova E, Krjutškov K, Nurmi K, Eklund K, Lagerstedt A, Helminen M, Martelius T, Mustjoki S, Taipale J, Saarela J, Kere J, Varjosalo M, Seppänen M. 2017. Damaging heterozygous mutations in NFKB1 lead to diverse immunologic phenotypes. Journal of Allergy and Clinical Immunology 140:782-796.

39. Schipp C, Nabhani S, Bienemann K, Simanovsky N, Kfir-Erenfeld S, Assayag-Asherie N, Oommen PT, Revel-Vilk S, Hönscheid A, Gombert M, Ginzel S, Schäfer D, Laws H-J, Yefenof E, Fleckenstein B, Borkhardt A, Stepensky P, Fischer U. 2016. Specific antibody deficiency and autoinflammatory disease extend the clinical and immunological spectrum of heterozygous NFKB1 loss-of-function mutations in humans. Haematologica 101:e392-e396.

40. Mills EL, Ryan DG, Prag HA, Dikovskaya D, Menon D, Zaslona Z, Jedrychowski MP, Costa ASH, Higgins M, Hams E, Szpyt J, Runtsch MC, King MS, McGouran JF, Fischer R, Kessler BM, McGettrick AF, Hughes MM, Carroll RG, Booty LM, Knatko EV, Meakin PJ, Ashford ML, Modis LK, Brunori G, Sevin DC, Fallon PG, Caldwell ST, Kunji ERS, Chouchani ET, Frezza C, Dinkova-Kostova AT, Hartley RC, Murphy MP, O'Neill LA. 2018. Itaconate is an antiinflammatory metabolite that activates Nrf2 via alkylation of KEAP1. Nature 556:113-117.

41. Mulvaney KM, Matson JP, Siesser PF, Tamir TY, Goldfarb D, Jacobs TM, Cloer EW, Harrison JS, Vaziri C, Cook JG, Major MB. 2016. Identification and Characterization of MCM3 as a Kelch-like ECH-associated Protein 1 (KEAP1) Substrate. Journal of Biological Chemistry 291:23719-23733.

42. Chang Y, Zhang X, Horton JR, Upadhyay AK, Spannhoff A, Liu J, Snyder JP, Bedford MT, Cheng X. 2009. Structural basis for G9a-like protein lysine methyltransferase inhibition by BIX-01294. Nature Structural \& Molecular Biology 16:312-317.

43. Mildenberger J, Johansson I, Sergin I, Kjobli E, Damas JK, Razani B, Flo TH, Bjorkoy G. 2017. N-3 PUFAs induce inflammatory tolerance by formation of KEAP1-containing SQSTM1/p62-bodies and activation of NFE2L2. Autophagy 13:1664-1678.

44. Wimmers F, Donato M, Kuo A, Ashuach T, Gupta S, Li C, Dvorak M, Foecke MH, Chang SE, Hagan T, De Jong SE, Maecker HT, van der Most R, Cheung P, Cortese M, Bosinger SE, Davis M, Rouphael N, Subramaniam S, Yosef N, Utz PJ, Khatri P, Pulendran B. 2021. The single-cell epigenomic and transcriptional landscape of immunity to influenza vaccination. Cell 184:3915-3935.e21.

45. Chen X, El Gazzar M, Yoza BK, McCall CE. 2009. The NF-kappaB factor RelB and histone H3 lysine methyltransferase G9a directly interact to generate epigenetic silencing in endotoxin tolerance. J Biol Chem 284:27857-65.

46. De Santa F, Narang V, Yap ZH, Tusi BK, Burgold T, Austenaa L, Bucci G, Caganova M, Notarbartolo S, Casola S, Testa G, Sung W-K, Wei C-L, Natoli G. 2009. Jmjd3 contributes to the control of gene expression in LPS-activated macrophages. The EMBO Journal 28:3341-3352. 
47. Wu L, Cao J, Cai WL, Lang SM, Horton JR, Jansen DJ, Liu ZZ, Chen JF, Zhang M, Mott BT, Pohida K, Rai G, Kales SC, Henderson MJ, Hu X, Jadhav A, Maloney DJ, Simeonov A, Zhu S, Iwasaki A, Hall MD, Cheng X, Shadel GS, Yan Q. 2018. KDM5 histone demethylases repress immune response via suppression of STING. PLOS Biology 16:e2006134.

48. Zhou Q, Zhang Y, Wang B, Zhou W, Bi Y, Huai W, Chen X, Chen Y, Liu Z, Liu X, Zhan Z. 2020. KDM2B promotes IL-6 production and inflammatory responses through Brg1-mediated chromatin remodeling. Cellular \& Molecular Immunology 17:834-842.

49. Zhang X, Wang Y, Yuan J, Li N, Pei S, Xu J, Luo X, Mao C, Liu J, Yu T, Gan S, Zheng Q, Liang Y, Guo W, Qiu J, Constantin G, Jin J, Qin J, Xiao Y. 2018. Macrophage/microglial Ezh2 facilitates autoimmune inflammation through inhibition of Socs3. Journal of Experimental Medicine 215:1365-1382.

50. Bugide S, Gupta R, Green MR, Wajapeyee N. 2021. EZH2 inhibits NK cell-mediated antitumor immunity by suppressing CXCL10 expression in an HDAC10-dependent manner. Proceedings of the National Academy of Sciences 118:e2102718118.

51. Wakabayashi N, Itoh K, Wakabayashi J, Motohashi H, Noda S, Takahashi S, Imakado S, Kotsuji T, Otsuka F, Roop DR, Harada T, Engel JD, Yamamoto M. 2003. Keap1-null mutation leads to postnatal lethality due to constitutive Nrf2 activation. Nat Genet 35:238-45.

52. Ramirez-Carrozzi VR, Braas D, Bhatt DM, Cheng CS, Hong C, Doty KR, Black JC, Hoffmann A, Carey M, Smale ST. 2009. A unifying model for the selective regulation of inducible transcription by CpG islands and nucleosome remodeling. Cell 138:114-28.

53. Burns V, Kerppola TK. 2012. Opposite orientations of a transcription factor heterodimer bind DNA cooperatively with interaction partners but have different effects on interferon-beta gene transcription. J Biol Chem 287:31833-44.

54. Tong AJ, Liu X, Thomas BJ, Lissner MM, Baker MR, Senagolage MD, Allred AL, Barish GD, Smale ST. 2016. A Stringent Systems Approach Uncovers Gene-Specific Mechanisms Regulating Inflammation. Cell 165:165-179.

55. Itoh K, Chiba T, Takahashi S, Ishii T, Igarashi K, Katoh Y, Oyake T, Hayashi N, Satoh K, Hatayama I, Yamamoto M, Nabeshima Y. 1997. An Nrf2/small Maf heterodimer mediates the induction of phase II detoxifying enzyme genes through antioxidant response elements. Biochem Biophys Res Commun 236:313-22. 
A

- - Keap1+/+ Nrf2-l- \#3

- Keap1-/- Nrf2-/- \#4

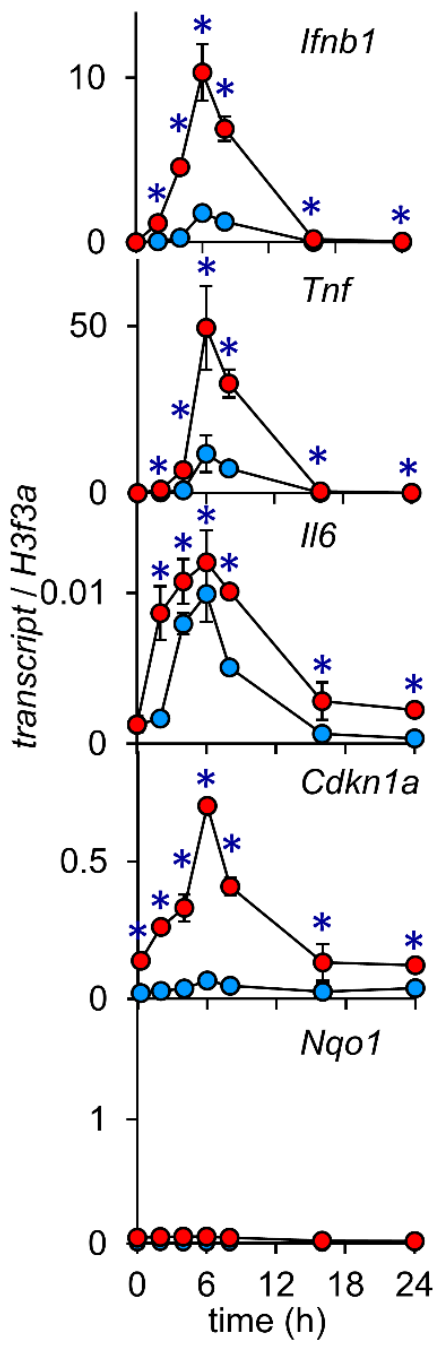

B

$\square$ Keap1+/+ Nrf2-/- \#2

$\square$ Keap1+/+ Nrf2-/- \#2 + S.v.

$\square$ Keap1-/- Nrf2-/- \#4

2 Keap1-/- Nrf2-/- \#4 + S.v.
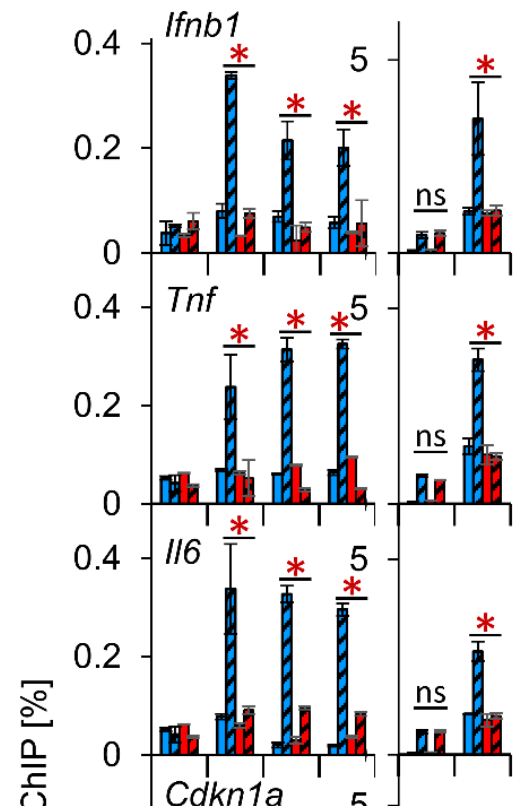

D

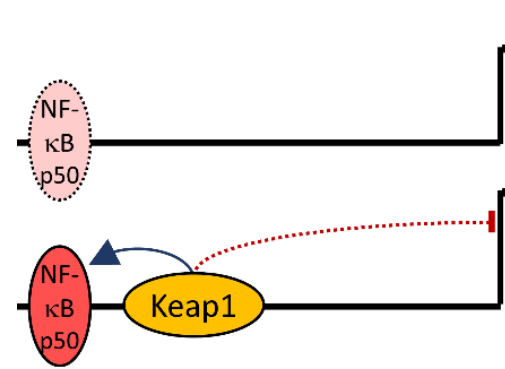

C

Fig. 1

Keap1+/+ Nrf2-/- \#1

Z Keap1+/+ Nrf2-/- \#1 + S.V.

口 Keap1-/- Nrf2-/- \#3

口 Keap1-/- Nrf2-/- \#3 + S.v.

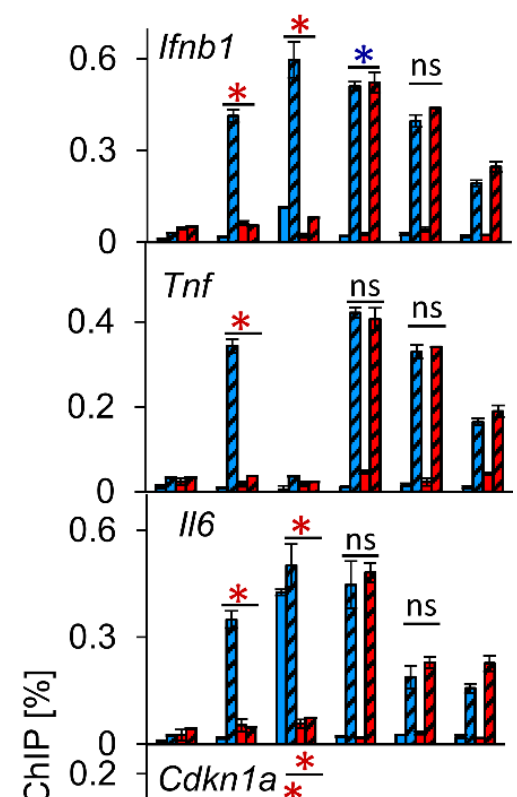

Figure 1. Virus infection induces higher cytokine transcript levels in Keap1-/- MEFs than in MEFs with intact

Keap1, and has opposite effects on Keap1 binding at cytokine and at cell cycle genes; Keap1 is required for G9a, GLP and NFKB p50 recruitment, and for H3K9me2 deposition. 
(A) Virus infection induces higher levels of cytokine transcription in Keap1-/- MEFs than in MEFs with intact Keap1. MEFs with intact Keap1 (blue) and MEFs with Keap1-/- deletions (red), each with Nrf2-/- deletions, were infected with Sendai virus. The levels of the transcripts indicated in the graphs were measured by RT-qPCR at the times after virus infection indicated on the bottom graph. The line graphs show the results (mean $\pm 2 * S D)$ of a representative experiment in which Keap1+/+ Nrf2-/- \#3 and Keap1-/- Nrf2-/- \#4 MEFs were compared. The \# after each genotype reflects a MEF population that was isolated from an independent embryo. The reproducibility of Keap1 effects on transcript levels were evaluated in 3-7 independent sets of MEFs by performing two-factor ANOVA analyses (* $p<0.0005)$.

(B) Virus infection has opposite effects on Keap1 binding to cytokine versus cell cycle genes, and Keap1 is required for G9a and GLP to bind and to deposit H3K9me2 upon virus infection. MEFs with intact Keap1 (blue bars) and MEFs with Keap1-/- deletions (red bars), each with Nrf2-/- deletions, were infected with mock (solid bars) or Sendai virus (S.v., striped bars). The levels of Keap1, G9a, GLP and IRF3 binding, and of H3K9me2 were measured 6 hours after infection at the genes indicated in the graphs using the antibodies indicated. The bar graphs show the results (mean $\pm 2 * S D)$ of a representative experiment in which Keap1+/+ Nrf2-/- \#2 and Keap1-/- Nrf2-/- \#4 MEFs were compared. The reproducibility of Keap1 effects on G9a, GLP and IRF3 binding, and on H3K9me2 were evaluated in 2-5 independent sets of MEFs by two-factor ANOVA analyses ( ${ }^{*} p<0.001$, blue - increase, red decrease).

(C) Keap1 is required for NFKB p50 to bind both virus induced and uninduced genes. MEFs with intact Keap1 (blue bars) and MEFs with Keap1-/- deletions (red bars), each with Nrf2-/- deletions, were infected with mock (solid bars)

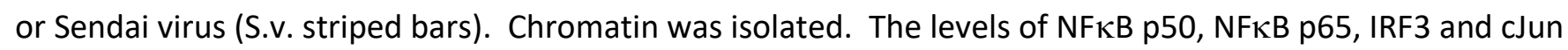
binding were measured 6 hours after infection at the genes indicated in the graphs using the antibodies indicated at the bottom. The bar graphs show the results (mean $\pm 2 * S D)$ of a representative experiment in which Keap1+/+ Nrf2-/- \#1 and Keap1-/- Nrf2-/- \#3 MEFs were compared. The reproducibility of Keap1 effects on NFkB p50 and NFKB p65 binding were evaluated in 4-6 independent sets of MEFs by two-factor ANOVA analyses $\left({ }^{*} p<0.001\right.$, blue - increase, red - decrease).

(D) The diagrams compare effects of virus infection on Keap1 binding, and Keap1 effects on G9a, GLP and NFKB p50 binding, on H3K9me2 deposition, and on transcription at cytokine versus cell cycle associated genes. The blue arrows indicate effects that are required for binding or for deposition. The red arcs and bars indicate effects that moderate transcription. Dotted lines and ovals indicate differences between different genes and MEFs. 
A

$-\square-$ Keap1+/+ Nrf2-/- \#6

$-\triangle-$ Keap1+/+ Nrf2-/- \#6, BIX01294

$\rightarrow$ ㅁ Keap 1-/- Nrf2-/- \#5

$-\triangle$ Keap1-/- Nrf2-/- \#5, BIX01294

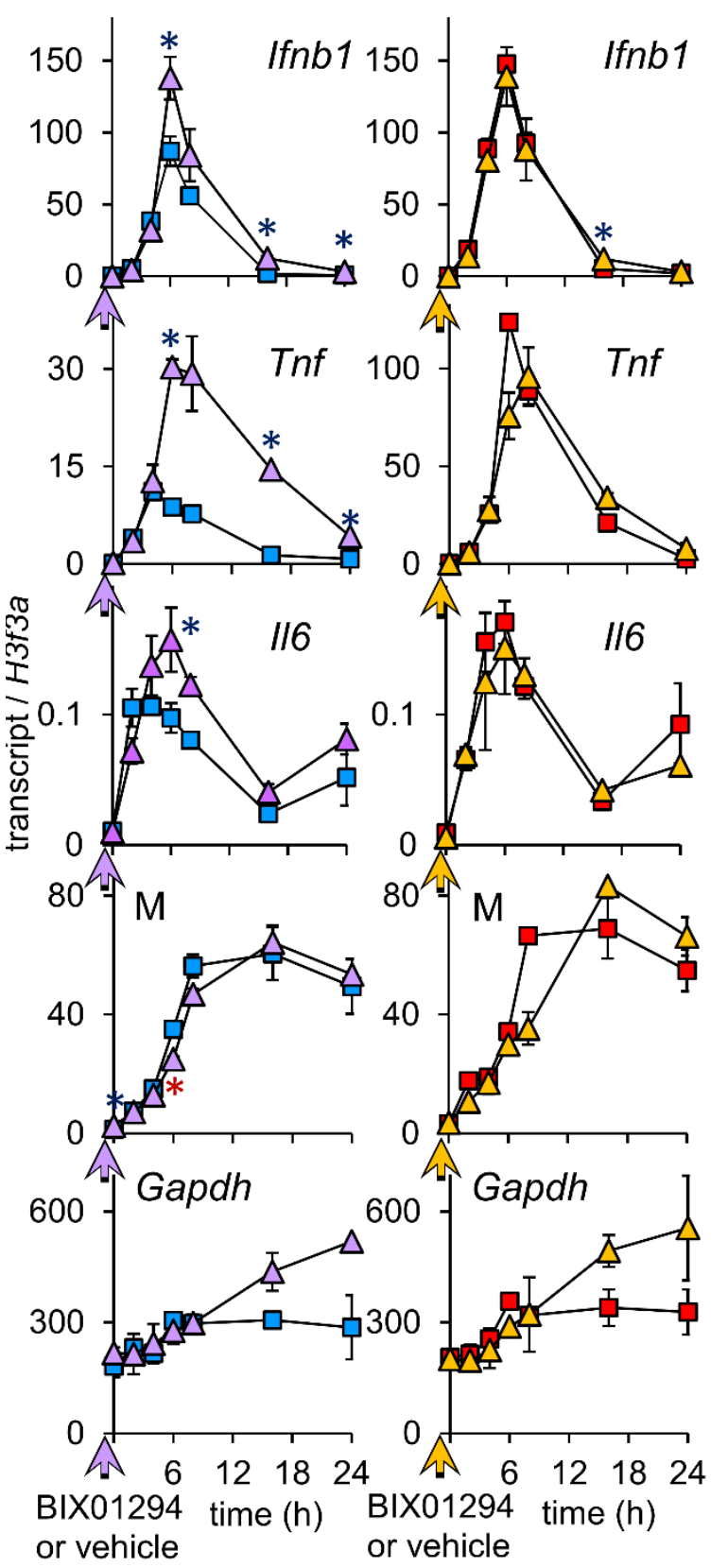

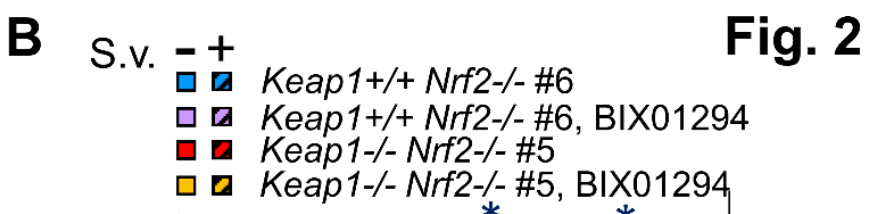

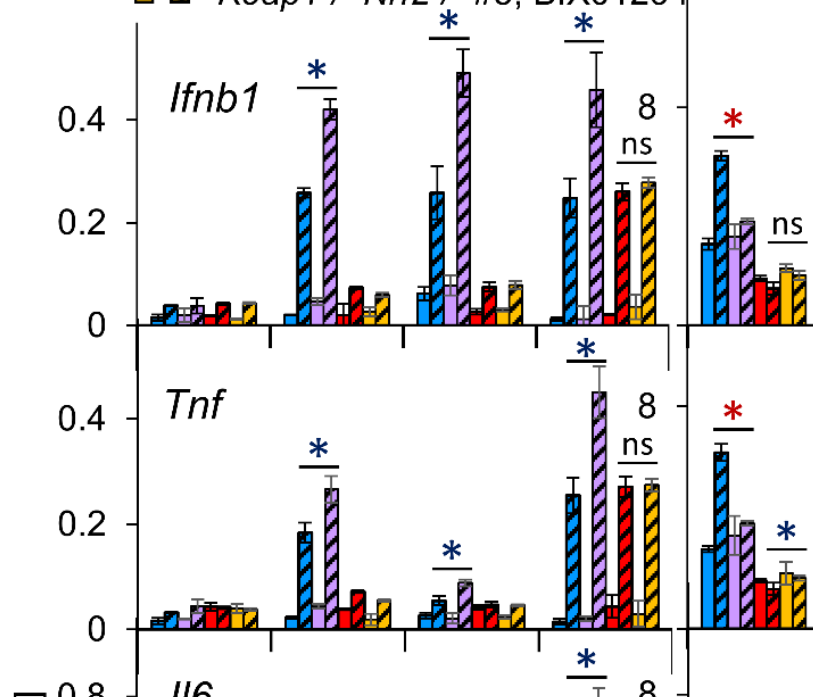

C
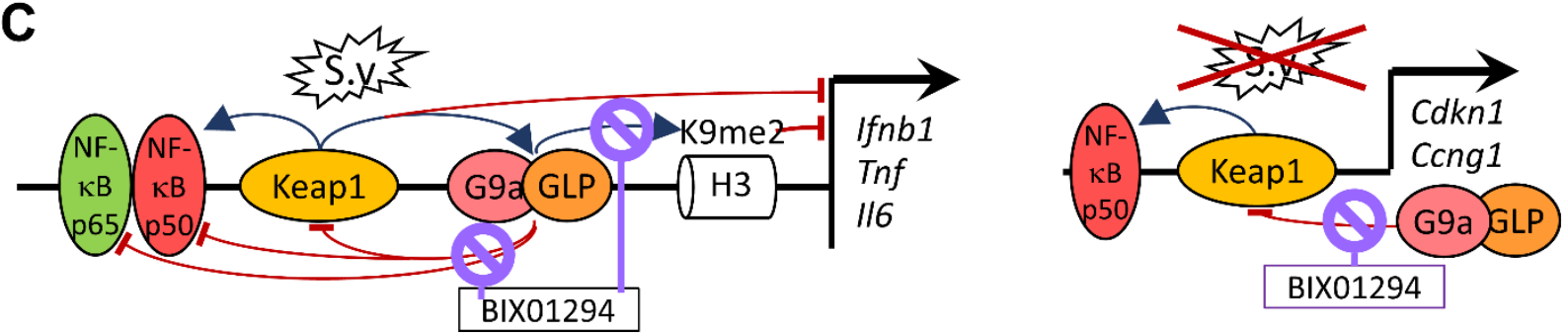

Figure 2. Inhibition of G9a-GLP enhances the transcription of virus induced genes in MEFs with intact Keap1, and augments Keap1 binding to different genes in uninfected and in virus infected MEFs. 
bioRxiv preprint doi: https://doi.org/10.1101/2022.02.08.479619; this version posted February 10,2022 . The copyright holder for this preprint (which was not certified by peer review) is the author/funder, who has granted bioRxiv a license to display the preprint in perpetuity. It is made available under aCC-BY-NC 4.0 International license.

(A) BIX01294 enhances the transcription of virus induced genes in MEFs with intact Keap1 selectively. MEFs with intact Keap1 (left graphs) and MEFs with Keap1-/- deletions (right graphs), each with Nrf2-/- deletions, were cultured with $20 \mu \mathrm{M}$ BIX01294 or vehicle starting an hour before virus infection (arrowhead on time axis). The levels of the transcripts indicated in the graphs were measured at the times after virus infection indicated at the bottom. The line graphs show the results of a representative experiment in which Keap1+/+ Nrf2-/- \#6 and Keap1/- Nrf2-/- \#5 MEFs were compared. The reproducibility of BIX01294 effects on transcription were evaluated in 2-4 independent sets of MEFs by two-factor ANOVA analyses ( ${ }^{*} p<0.001$, blue - increase, red - decrease).

(B) BIX01294 augments Keap1 binding to different genes in virus infected and in uninfected MEFs. MEFs with intact Keap1 and MEFs with Keap1-/- deletions, each with Nrf2-/- deletions, were cultured with $20 \mu \mathrm{M}$ BIX01294 or vehicle for an hour before mock (solid bars) or virus (striped bars) infection. The levels of Keap1, NFKB p50 and NFKB p65 binding, and of H3K9me2 were measured 6 hours after infection at the genes indicated in the graphs using the antibodies indicated. The bar graphs show the results of a representative experiment in which Keap1+/+ Nrf2-/- \#6 and Keap1-/- Nrf2-/- \#5 MEFs were compared. The reproducibility of BIX01294 effects on Keap1, NFKB p50 and NFKB p65 binding, and on H3K9me2 were evaluated in 2-5 independent sets of MEFs by two-factor ANOVA analyses ( $* p<0.005$, blue - increase, red - decrease).

(C) The diagrams compare BIX01294 effects on Keap1 and NFKB p50 binding, on H3K9me2 deposition, and on transcription at cytokine genes in virus infected MEFs and at cell cycle associated genes in uninfected MEFs. The blue arrows indicate effects that are required for binding or for deposition. The red arcs and bars indicate effects that inhibit or moderate binding, deposition, or transcription. 
bioRxiv preprint doi: https://doi.org/10.1101/2022.02.08.479619; this version posted February 10, 2022. The copyright holder for this preprint (which was not certified by peer review) is the author/funder, who has granted bioRxiv a license to display the preprint in perpetuity. It is made available under aCC-BY-NC 4.0 International license.

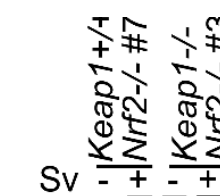

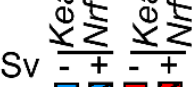

口耳वDMSO

И BIX01294

乙 $\triangle \mathrm{MS012}$

乙

A

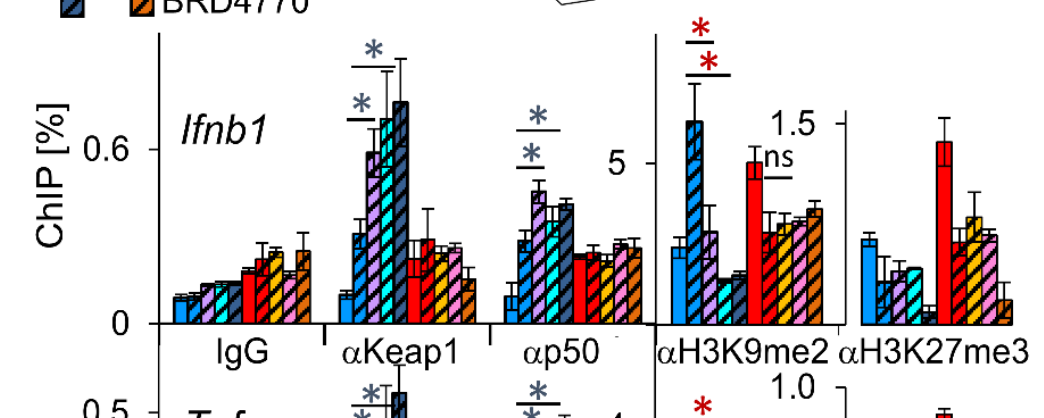

BIX01294

MS012

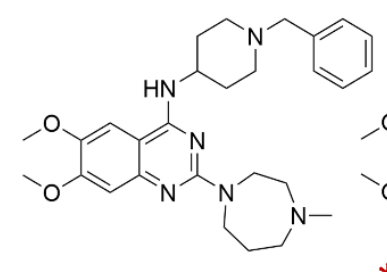

$\frac{2}{0}$

$\frac{2}{\frac{2}{0}}_{0}^{0.5}$

$\frac{2}{\frac{0}{0}}$

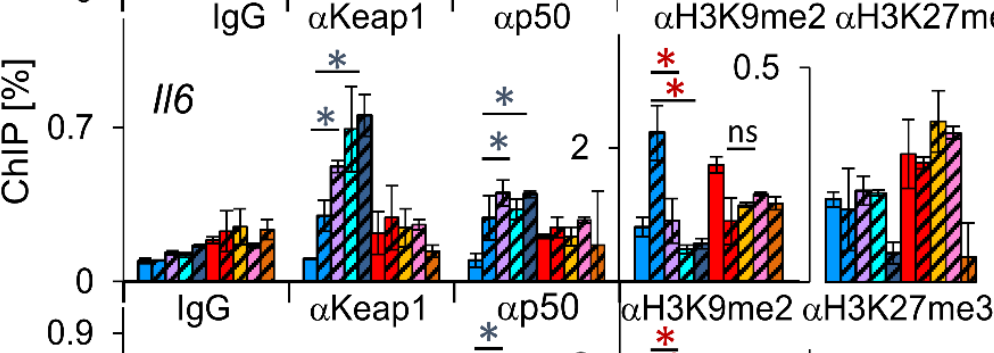

递

$\frac{\sqrt[0]{0}}{\frac{0}{0}} 1$

$\operatorname{Tnf}$
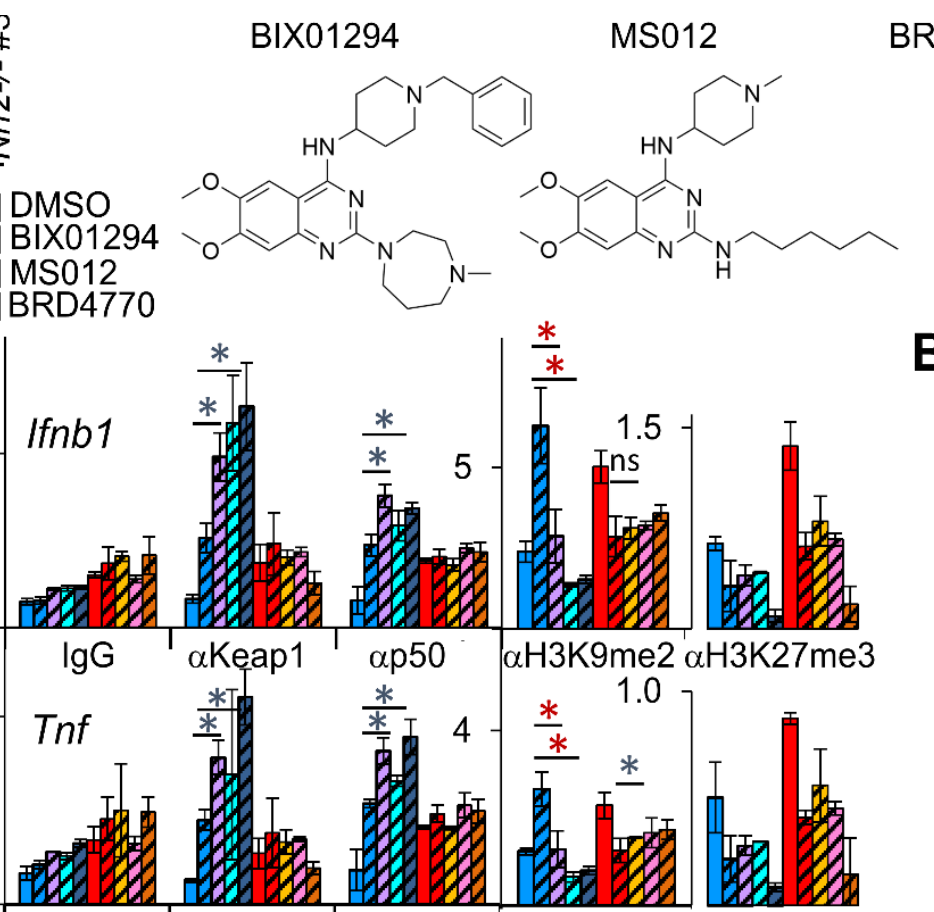

B

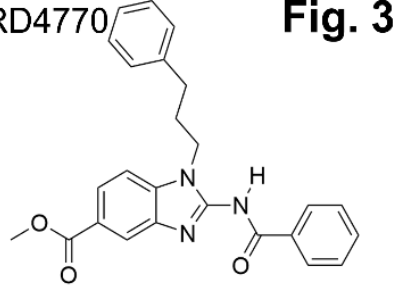

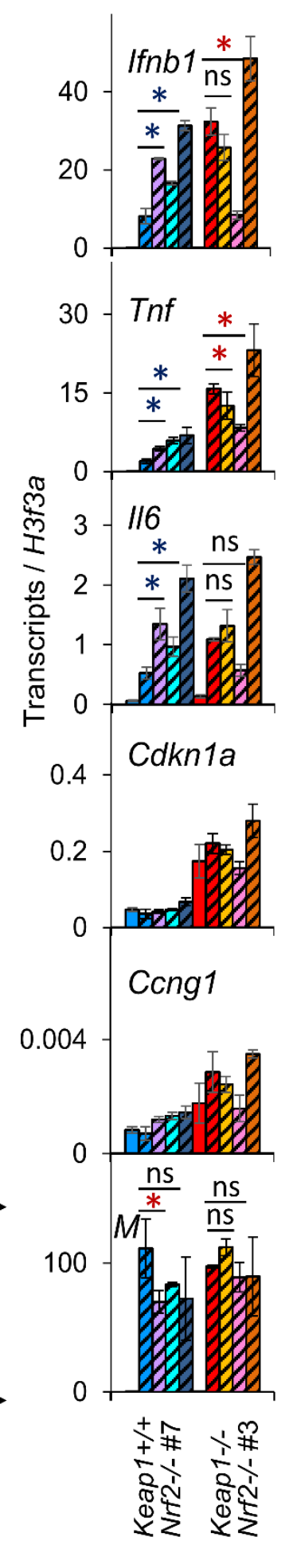

Fig. 3

Figure 3. Structurally dissimilar G9a-GLP inhibitors augment Keap1 and NFKB p50 binding to virus induced genes, and enhance the transcription of virus induced genes in MEFs with intact Keap1. 
(A) Different G9a-GLP inhibitors have parallel effects on Keap1 and NFKB p50 binding to virus induced genes in MEFs with intact Keap1. MEFs with intact Keap1 (cool colors) and MEFs with Keap1-/- deletions (warm colors), each with Nrf2-/- deletions, were cultured with $20 \mu \mathrm{M}$ BIX01294 starting an hour before infection, or with $1 \mu \mathrm{M}$ MS012, $20 \mu \mathrm{M}$ BRD4770 or vehicle starting 48 hours before infection. The levels of Keap1 and NFKB p50 binding, and H3K9me2 and H3K27me3 were measured 6 hours after mock (solid bars) or virus (striped bars) infection at the genes that are indicated in the graphs using the antibodies indicated at the bottom. The bar graphs show the results of a representative experiment in which Keap1+/+ Nrf2-/- \#7 and Keap1-/- Nrf2-/- \#3 MEFs were compared. The MEFs that were analyzed in panels A and B were cultured in parallel, and the legend at the top of the figure applies to both panels. The reproducibility of BIX01294 and MS012 effects on Keap1 and NFאB p50 binding, and on H3K9me2 were evaluated in 2-4 independent sets of MEFs by two-factor ANOVA analyses $\left({ }^{*} p<0.005\right.$, blue increase, red-decrease).

(B) Several G9a-GLP inhibitors have distinct effects on virus induced gene transcription in MEFs with intact Keap1 versus MEFs with Keap1-/- deletions. MEFs with intact Keap1 (cool colors) and MEFs with Keap1-/- deletions (warm colors), each with Nrf2-/- deletions, were cultured with $20 \mu \mathrm{M}$ BIX01294 starting an hour before infection, or with $1 \mu \mathrm{M}$ MS012, $20 \mu \mathrm{M}$ BRD4770 or vehicle starting 48 hours before infection. The levels of the transcripts indicated in the graphs were measured 6 hours after mock (solid bars) or virus (striped bars) infection. The graphs show the results of a representative experiment in which Keap1+/+ Nrf2-/- \#7 and Keap1-/- Nrf2-/- \#3 MEFs were compared. The reproducibility of BIX01294 and MS012 effects on transcription were evaluated in 2-4 independent sets of MEFs by two-factor ANOVA analyses ( $* p<0.001$, blue - increase, red - decrease).

(C) The diagrams compare effects of G9a-GLP inhibitors on Keap1 and NFKB p50 binding, on H3K9me2 deposition, and on transcription at cytokine versus cell cycle associated genes in virus infected MEFs. The blue arrows indicate effects that are required for binding or for deposition. The red arcs and bars indicate effects that inhibit or moderate binding, deposition, or transcription. 
A

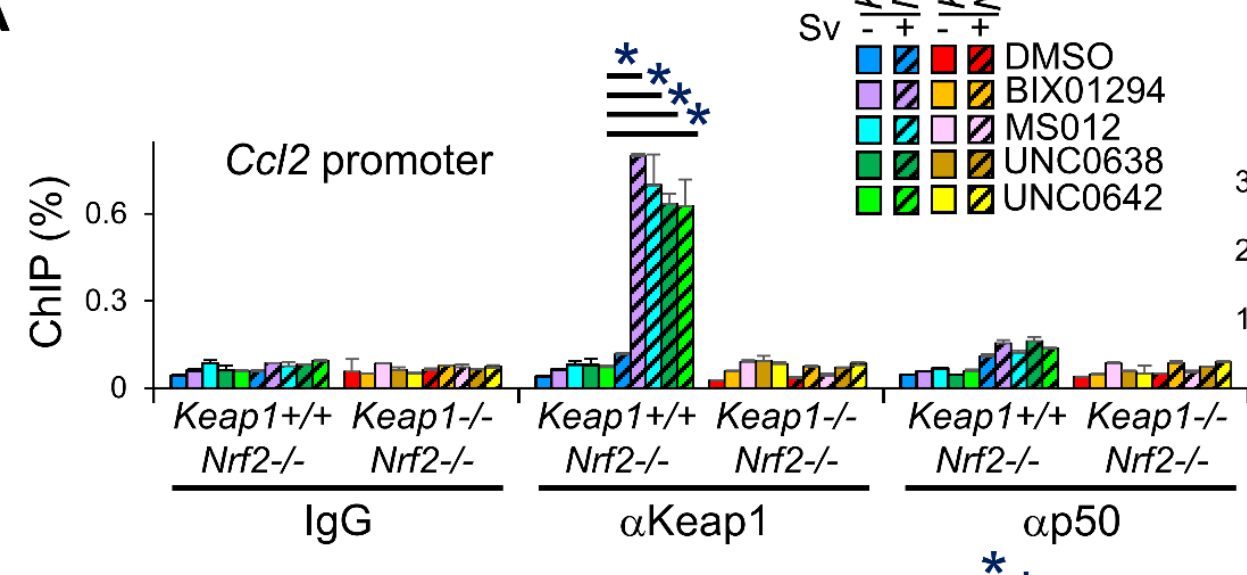

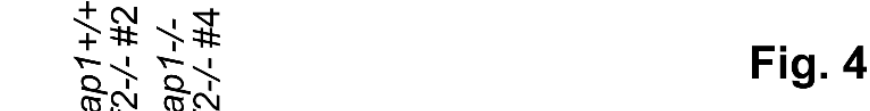

Fig. 4

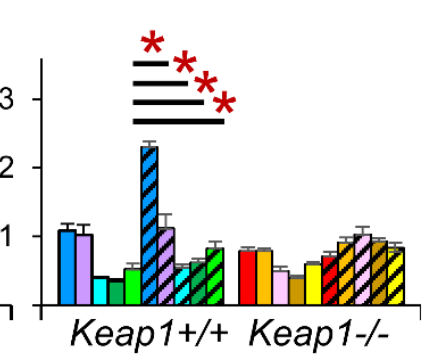

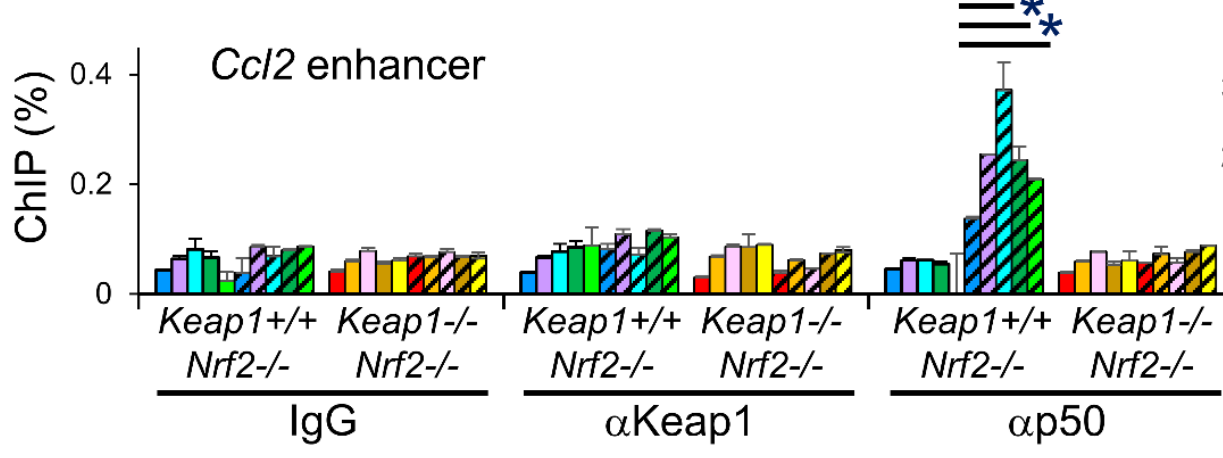

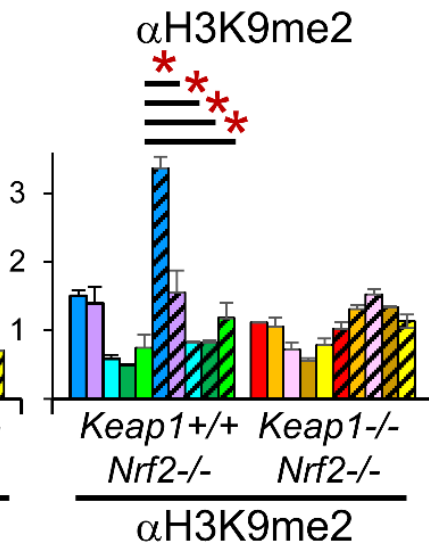

B

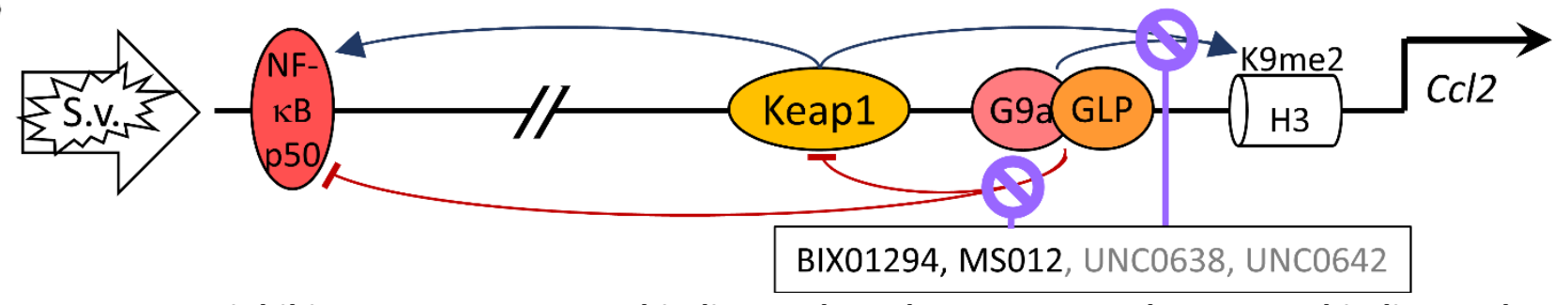

Figure 4. G9a-GLP inhibitors augment Keap1 binding to the $C c / 2$ promoter and NFKB p50 binding to the $C c / 2$ enhancer in virus infected MEFs.

(A) Keap1 binds to the $C \mathrm{Cl} 2$ promoter and is required for NFKB p50 to bind the $\mathrm{Cc} / 2$ enhancer and for $\mathrm{H} 3 \mathrm{~K} 9 \mathrm{me} 2$ deposition. MEFs with intact Keap1 (cool colors) and MEFs with Keap1-/- deletions (warm colors), each with Nrf2/- deletions, were cultured for one hour with $20 \mu \mathrm{M}$ BIX01294, or for 48 hours with $1 \mu \mathrm{M}$ MS012, $10 \mu \mathrm{M}$ UNC0638, $10 \mu \mathrm{M}$ UNC0642, or vehicle before infection. The levels of Keap1 and NFKB p50 binding, and of H3K9me2 were measured $6 \mathrm{~h}$ after mock (solid bars) or virus (striped bars) infection at the $C c / 2$ promoter (upper graph) and at the $\mathrm{Ccl} 2$ enhancer (lower graph) using the antibodies indicated. The graphs show the results of a representative experiment in which Keap1+/+ Nrf2-/- \#2 and Keap1-/- Nrf2-/- \#4 MEFs were compared. The reproducibility of G9a-GLP inhibitor effects on Keap1 and NFKB p50 binding, and on H3K9me2 were evaluated in 2 experiments by two-factor ANOVA analyses ( ${ }^{*} p<0.005$, blue - increase, red - decrease).

(B) The diagram depicts effects of virus infection and G9a-GLP inhibitors on Keap1 and NFKB p50 binding and on H3K9me2 deposition at the $C \mathrm{C} / 2$ enhancer and promoter in virus infected MEFs. The blue arrows indicate effects that are required for binding or for deposition. The red arcs and bars indicate effects that inhibit or moderate binding or deposition. Compounds that had different effects in different experiments are indicated in grey type. 


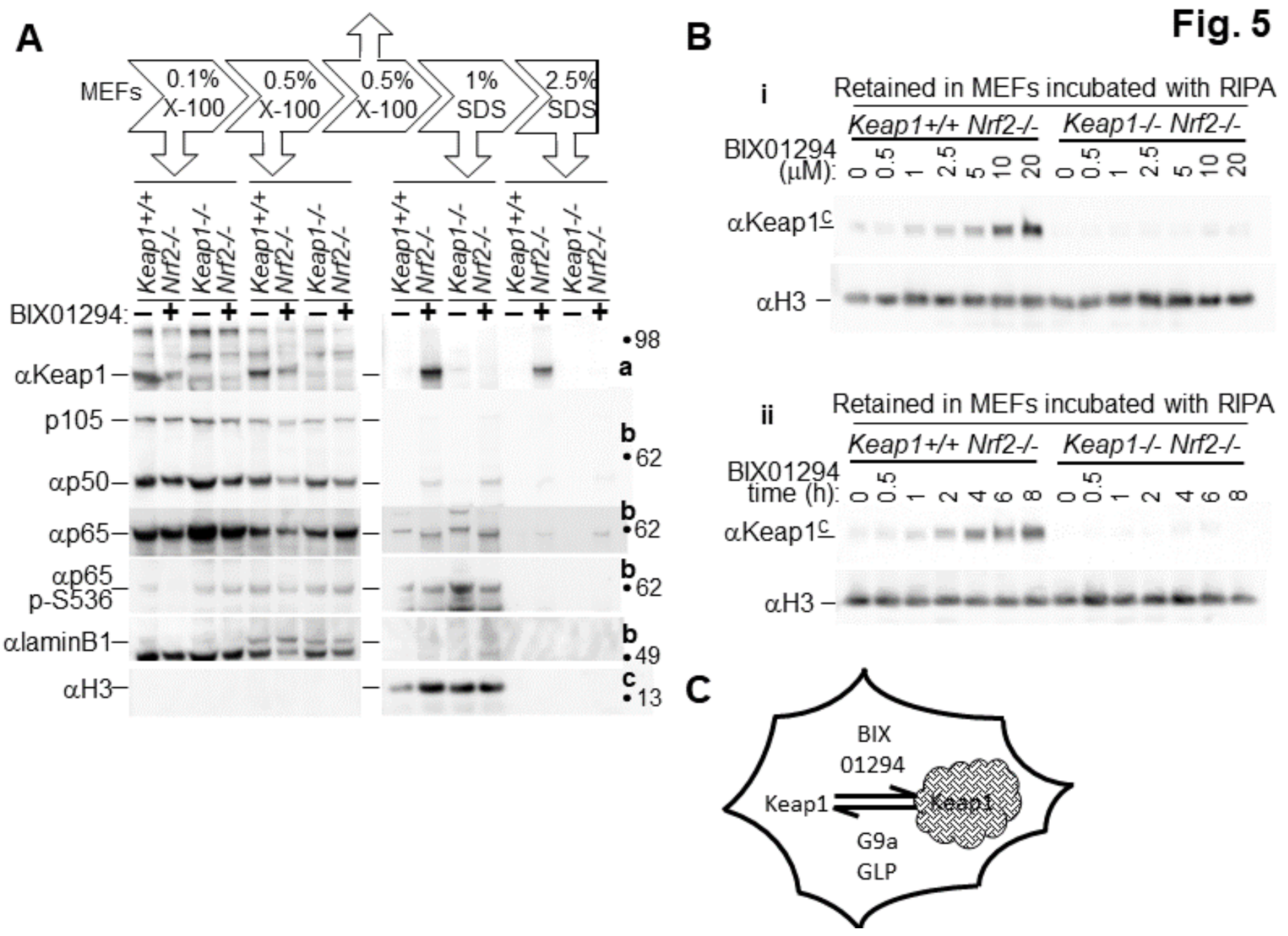

Figure 5. G9a-GLP inhibitors stabilize Keap1 retention in permeabilized MEFs.

(A) Culture with BIX01294 stabilizes Keap1 and NFKB p50 retention in MEFs that are incubated with detergents.

The MEFs that are indicated above the lanes were cultured with vehicle (-) or with $20 \mu \mathrm{M}$ BIX01294 (+) for 48

hours. After culture, the MEFs were incubated sequentially in buffers that contained the detergents indicated

above the lanes (see Materials and Methods). The proteins that were released during incubation with each

detergent were analyzed by immunoblotting using the antibodies indicated to the left of the images. No proteins

were detected in the lanes that were loaded with supernatants from a second incubation with $0.5 \%$ Triton X-100

(up arrow in the diagram at the top), and those lanes are not shown. The same samples were analyzed on several

membranes as indicated to the right of the images $(a, b, c)$. The images show results from a representative

experiment in which Keap1+/+ Nrf2-/-\#2 and Keap1-/- Nrf2-/- \#4 MEFs were compared. The mobilities of

molecular weight markers are indicated to the right of the images. 
bioRxiv preprint doi: https://doi.org/10.1101/2022.02.08.479619; this version posted February 10,2022. The copyright holder for this preprint (which was not certified by peer review) is the author/funder, who has granted bioRxiv a license to display the preprint in perpetuity. It is made available under aCC-BY-NC 4.0 International license.

(B) Effects of the concentration of BIX01294 and of the time of culture on Keap1 retention in MEFs. The MEFs that are indicated above the images were cultured with the indicated concentrations $(\mu \mathrm{M})$ of BIX01294 for $4 \mathrm{~h}(\mathrm{i}$, upper panel), and for the indicated times (h) with $20 \mu \mathrm{M}$ BIX01294 (ii, lower panel). After culture, the MEFs were incubated in RIPA buffer, and the proteins that were retained in the MEFs were analyzed by immunoblotting. The images show $\alpha \operatorname{Keap} 1^{C}$ and $\alpha$ Vinculin immunoblots of the proteins that were retained in the MEFs. The images show the results from a representative experiment in which Keap1+/+ Nrf2-/- \#8 and Keap1-/- Nrf2-/- \#5 MEFs were compared.

(C) The diagram illustrates the stabilization of Keap1 retention in MEFs by G9a-GLP inhibition. 
bioRxiv preprint doi: https://doi.org/10.1101/2022.02.08.479619; this version posted February 10, 2022. The copyright holder for this preprint (which was not certified by peer review) is the author/funder, who has granted bioRxiv a license to display the preprint in perpetuity. It is made available under aCC-BY-NC 4.0 International license.
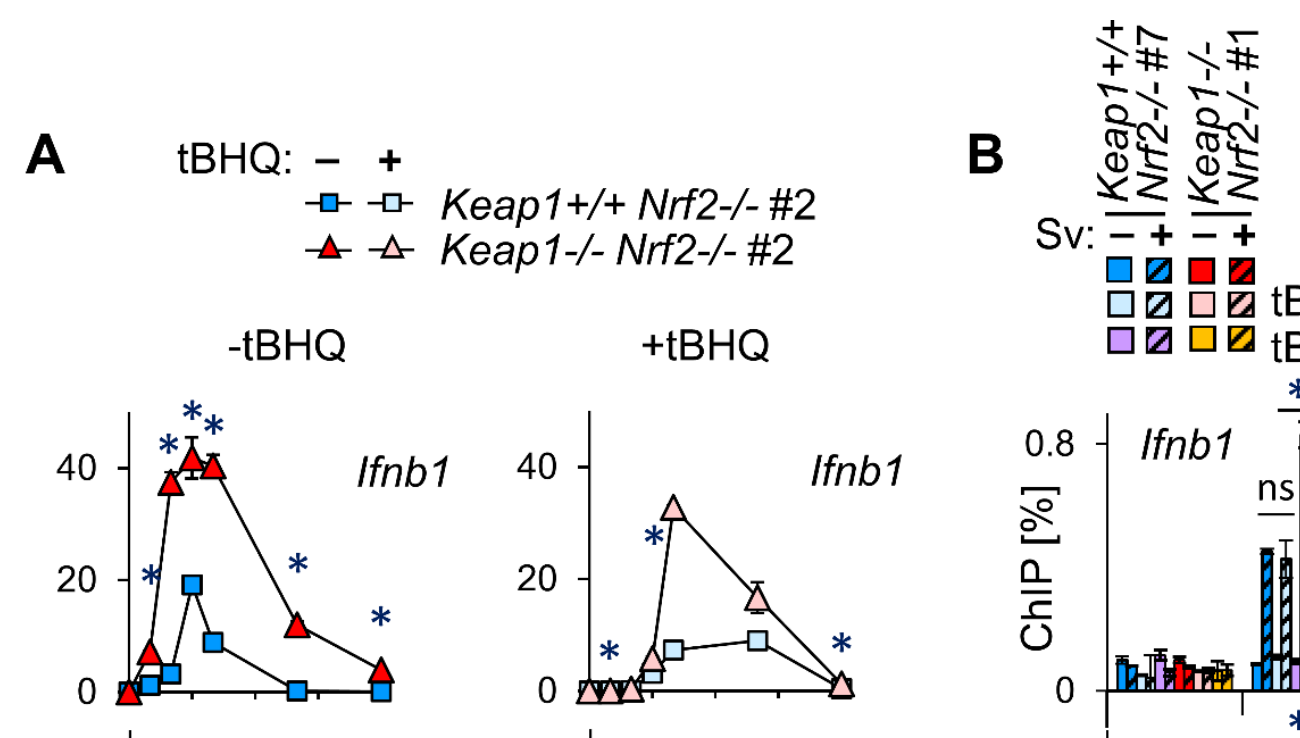

Fig. 6
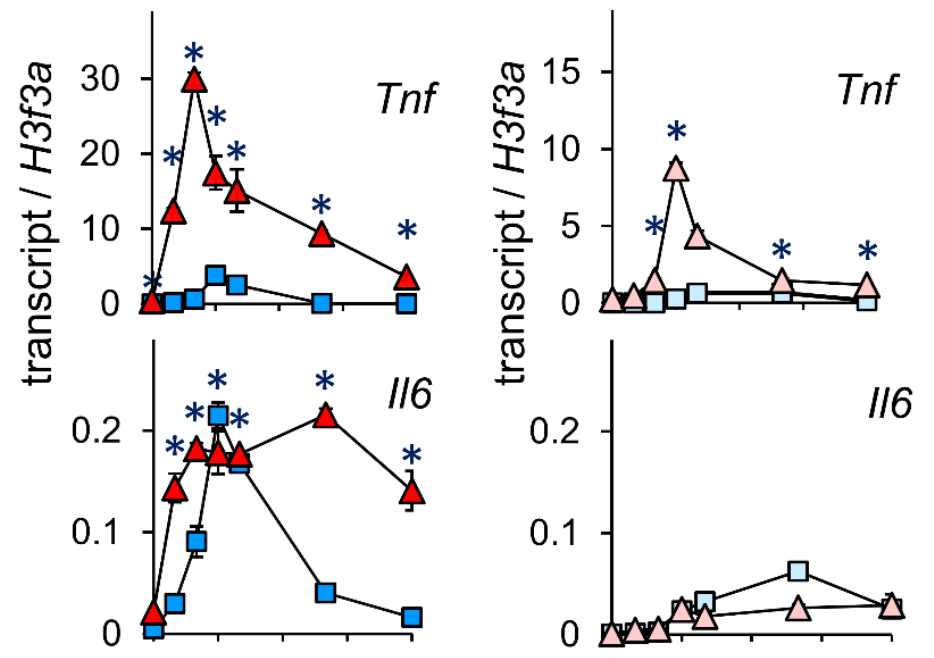

B

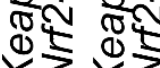

Sv: $\frac{1<}{-+} \leq+$

ロロ古

$\square \square \square \mathrm{tBHQ}$

$\square \square \square \square \mathrm{tBHQ}+\mathrm{BIX01294}$
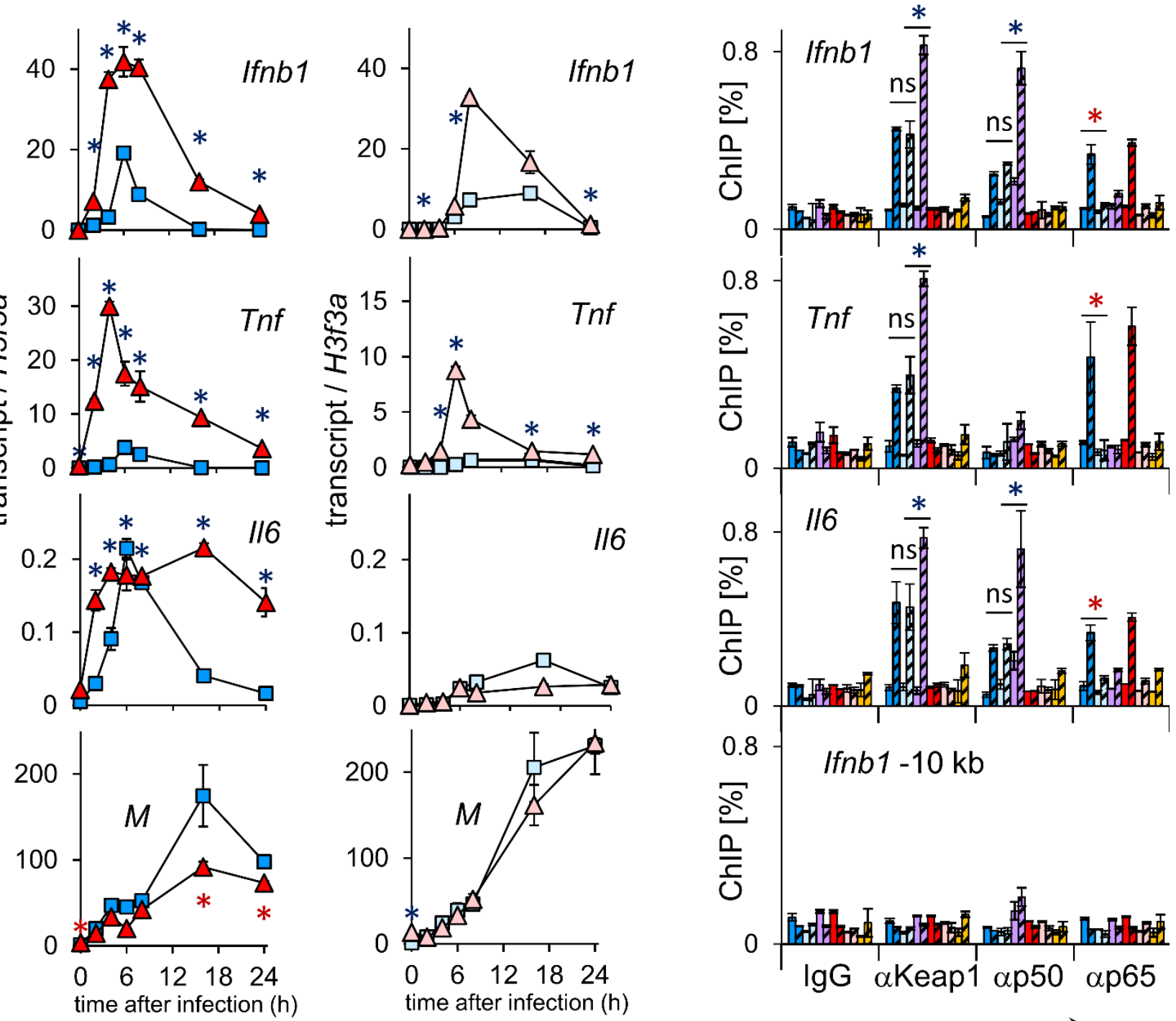

C

time after infection (h) 
(A) Keap1 and tBHQ moderate the transcription of virus induced genes independently of each other. MEFs with intact Keap1 and MEFs with Keap1-/- deletions, each with Nrf2-/- deletions, were cultured with vehicle (left graphs) or with $50 \mu \mathrm{M} \mathrm{tBHQ}$ (right graphs) for 24 hours before virus infection. The levels of the transcripts indicated in the graphs were measured at the times after virus infection indicated at the bottom. The graphs show the results of a representative experiment in which Keap1+/+ Nrf2-/- \#2 and Keap1-/- Nrf2-/- \#2 MEFs were compared. The reproducibility of Keap1 effects on transcription in MEFs that were cultured with $\mathrm{BH}$ Q or with vehicle were evaluated in two independent sets of MEFs by two-factor ANOVA analyses ( ${ }^{*} p<0.0005$, blue: increase, red: decrease).

(B) tBHQ inhibits NFкB p65 binding to virus induced genes independently of Keap1. MEFs with intact Keap1 (cool colors) and MEFs with Keap1-/- deletions (warm colors), each with Nrf2-/- deletions, were cultured with $50 \mu \mathrm{M}$ tBHQ , $50 \mu \mathrm{M} \mathrm{tBHQ}$ and $20 \mu \mathrm{M}$ BIX01294, or vehicle for 24 hours before infection. The levels of Keap1, NFкB p50 and NFKB p65 binding were measured 6 hours after mock (solid bars) or virus (striped bars) infection at the genes indicated in the graphs using the antibodies indicated at the bottom. The graphs show the results of a representative experiment in which Keap1+/+ Nrf2-/- \#7 and Keap1-/- Nrf2-/-\#1 MEFs were compared. The

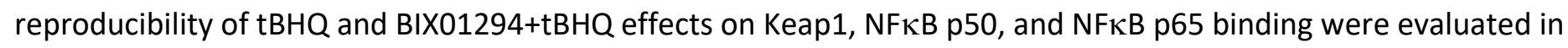
two independent sets of MEFs by two-factor ANOVA analyses ( ${ }^{*} p<0.005$, blue: increase, red: decrease).

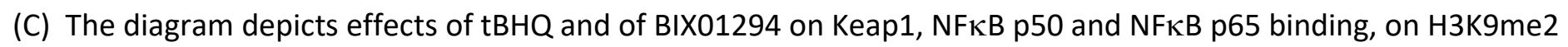
deposition, and on transcription at virus induced genes. The blue arrows indicate effects that are required for binding or for deposition. The red arcs and bars indicate effects that inhibit or moderate binding, deposition, or transcription. 